Kastamonu Eğitim Dergisi
$\begin{aligned} & \text { Kastamonu Education Journal } \\ & \text { Mart } 2020 \text { Cilt:28 Sayı:2 } \\ & \text { kefdergi.kastamonu.edu.tr }\end{aligned}$

\title{
Osmanlı Döneminde Kudüs'e Yahudi Göçü, İdari ve Sosyal Yapı ile Okullar
}

\section{Jewish Migration to Jerusalem, Administrative and Social Structure and Schools During Ottoman Period}

\author{
Ahmet Rıfat GÜZEY ${ }^{1}$ \\ Öz
}

Osmanlı dönemindeki seyyahlarının en önde gelen ismi olan Evliya Çelebi'nin meşhur Seyahat-nâmesini okuduğumuzda, Mescid-i Aksa konusunda mabede o günün şartlarında 800 kişinin hizmet ettiği geniş bir teşkilatlanmanın mevcut olduğu gözümüze çarpıyor. Bu harika teşkilatlanmayı sağlayan da tabii ki Osmanlı Devleti'nin bölgeye olan desteği idi. Mescid-i Aksa'da Ehl-i Sünnet Mezheplerden her birinin, birer hatibi ve imamı bulunması dışında, elli de müezzin mevcuttu. Diğer hizmet erbabını da buna ekleyince bakım işlerinin geniş bir yapıya sahip olduğu görülmektedir. Evliya Çelebi'den aldığımız bilgiler doğrultusunda, Osmanlı Cihan Devleti'nin bu eski ve mübarek ibadethaneye ne kadar büyük bir önem verdiğini göstermektedir. İslâm âleminin önemli mabetlerinden Mescid-i Aksa altı Osmanlı padişahı tarafından çeşitli onarımlarla yenilenmiştir. Şu andaki mevcut kubbesi 1752 tarihinde III. Osman tarafından yaptırıldı. Avlusunda, yağmur duası için namaz kılınacağı sırada kullanılan ve görüntüsüyle harika bir sanat eseri olduğu mesajını veren bir minber vardır. 1388 yılında inşa edilen bu minberin mermer sütunları hemen dikkat çekiyor. Bir diğer alanda Memluk'lerin 1482 yılında yaptığı şadırvanı, mabetteki en orijinal şadırvan olarak dikkatleri çekerken bugün eski görüntüsünü korumakta. Üstelik hemen yanında Eyyubi sanat eseri bir başka yuvarlak şadırvan daha mevcuttur. Harem-i Şerif-i bezeyen Kubbetü'I-Mirac, Kubbetü'n-Nebi, Kubbetü'I-Yusuf gibi diğer küçük yapıların hemen hepsinin Osmanlı'dan izler taşıdığını ve daha evvelinden kalan izlerin de itina ile korunmaya çalışıldığını görüyoruz. Osmanlılarla birlikte bu topraklarda kesintisiz 401 yıl hüküm süren bir Türk-i̇slâm medeniyeti tüm izleriyle bizleri kendine ram ediyor. Devlet-i Âli Osman'ın burada sağladığı barış ve güven atmosferi bugün yerini gerginlik ve kargaşaya bırakmış olmasına rağmen Kudüs'te yaşayanlar Türk'ün şefkat, merhamet ve adaletini bekliyor.

Anahtar Kelimeler: Osmanlı, İslâm, Türk, Yahudi, Kudüs

\section{Abstract}

Evliya Celebi, who has been the prominent explorer of the Ottoman period, described al-Masjid al-Aqsa in his famous travelogue called the Seyâhatnâme as "800 people are in service in al-Masjid-al-Aqsa. This enormous organization provided with the support of the Ottoman State. One preacher and one imam for every four sects and also fifty muezzins have been employed in al-Aqsa. Contrast other professional experts considering these numbers". This information we acquired from Evliya Celebi shows the importance that Ottoman State attached to this old and holy sanctuaries. Al-Masjid al-Aqsa, one of the most important sanctuaries of Islam, has been restored by six Sultans of the Ottoman. One dome remains standing was built by the command of Osman the 3rd in 1752. A gorgeous minbar stands in the courtyard which was built to use during rain prayer. Marble pillars of this minbar which built 1388, are still conspicuous. Mamluk water-tank in another vicinity that built 1482 remain standing, is accepted as the most original water-tank in Palestine is alongside with another tank with a sphere dome, which was an artwork of Ayyubids. Almost all of the small structures such as the Dome of the Ascension, Dome fo the Spirits and Jussef Dome decorates Haram al-Sharif carry the trace of Ottoman. A Turkish-Islamic civilization that reigns these lands uninterrupted for 401 years, subjugate us with all traces. Although the atmosphere of peace and reliance mediated through the Sublime Ottoman State has turned into civil disorder, the people who live in Jerusalem still expecting for the mercifulness and fairness of Turks.

Keywords: Ottoman, Islam, Turk, Jew, Jerusalem

${ }^{1}$ Kastamonu Üniversitesi, Eğitim Fakültesi, Türkçe ve Sosyal Bilimler Eğitimi Bölümü, Kastamonu, Türkiye, https://orcid.org/0000-0003-0931-886X Atıf / Citation: Güzey, A. R. (2020). Osmanlı döneminde kudüs'e yahudi göçü, idari ve sosyal yapı ile okullar. Kastamonu Education Journal, $28(2), 992-1007$. doi:10.24106/kefdergi.697853 


\section{Extended Abstract}

Jerusalem, which is one of the oldest motherlands of humanity, has always been the apple of mankind in terms of being a homeland for nearly 20 Prophets. This beautiful city attracts attention, for this reason, makes emotions alive that Tanpınar stated in lines;

\section{"Neither I'm in nor completely out of the time; \\ The indivisible flow of wide and solid moment"}

and surrounds all timelines lived. Breathing in such mystic geography that spiritual atmosphere excites souls, makes you feel like a time traveller having the head in the clouds and make you live all inner pleasures together.

Jerusalem was also acknowledged as a sacred city by three great Prophets his holiness Moses, Jesus and Mohammad (PBUH). Due to the added value of this reason, Jerusalem couldn't be shared in historical periods, passed from one hand to another and consequently, the smell of gunpowder in these lands has never been lacking. Floating rock is one of the most interesting points in al-Aqsa where His holiness Mohammad (PBUH) ascended.

The myth of Jerusalem is an arcane story of three religions and members of these beliefs. Because the word "Jerusalem" reminds of the struggle for existence of these three beliefs and their members. In absence of this faith, Jerusalem is just a city without any charm that consist of stone, wood and concrete. Extraordinary aura and life experiences make this ancient city special and charming. Mystery in such incidents ensouls all objects in this city.

The importance of Jerusalem in both religious and political terms and the fact that the people living in and around it belongs to different social structures and beliefs add many different features to the city. In this sense, it is natural that in the city where people who have more common characteristics, they have more common interests. From this point of view, religion is the main common point in the identity of the believers living in the city, spread to all places in Jerusalem.

This sacred city is esteemed for mankind because of the points mentioned and much more unnamed sentimental values above. Jerusalem, being named due to its sanctity, has besieged forty times during its history, destroyed 29 times partly and 3 completely. It is sacred because many civilizations such as Assyrian, Babylonian, Coptic, Greek, Polemi, Seleucid, Roman, Byzantine, Persian, Muslim Arab, Seljuk, Fatimid, Crusader, Mongolian, Mameluke, Ottoman, British, Israel, Jordan, Egypt, Syria, Lebanon, Iraq and finally Palestine had the risk and excitement to fight for this city.

These features, of course, inspire everyone to the excitement of investigating Jerusalem, peak the instinct to understand the reasons for the struggle and disagreements for this sacred city.

Al-Masjid Al-Aqsa is the orphan of the ummah fell into pieces. Tired of its position. Mehmet Akif inan, who considered commendable recently in literature as one of the "Seven Beautiful Man", illustrated Al-Masjid Al-Aqsa as;

"I dreamed Al-Aqsa last night, as a child crying,

Sidled over and pinned my forehead to its doorstep, gurgling like an underground river",

in his emotional poetry. This tragical condition of the unhappy masjid hit him hard as every Muslim.

Turks built many buildings such as mosque, madrasah, inn, bath, arch, bridge, bastion, prayer, imaret, fountain, water channel, fortification, complex and bazaar in Palestine and Jerusalem. Isn't it meaningful that British who took over the city after Turks dismantled the Abdul Hamid II clock tower in the city of Al-Khalil, showing a great example of vandalism? One wanders and tears up when you say Jerusalem like in the lines in poetry; "One half of my heart is Mecca and the other half is Medina; there is Jerusalem as a tulle on it". 


\section{Giriş}

Değişik zamanlarda Roma, Bizans ve İran (Buhl, 1977: 955) egemenliğinde yaşayan Kudüs, 638 senesinde Hz. Ömer zamanında İslâm hâkimiyetine katılmıştır. Yahudiler Hz. Ömer'e şehirde yerleşme talebinde bulunmuşlar, onların isteğine Hristiyanların karşı çıkmasına rağmen $\mathrm{Hz}$. Ömer' in zoruyla başlangıçta yetmiş civarındaki Yahudi ailenin şehirde yerleşmesine izin verilmiştir. Yahudiler, Hz. Ömer'den sonra gelen Müslüman idarecilere de aynı taleplerini devam ettirince yöredeki kısmi iskânın sürdüğü görülmektedir (Yiğitoğlu, 2017: 137). Emevi egemenliği döneminde Mescid-i Aksa onarılıp, Kubbetü's-Sahranın yapılışı, İslâmî dönemdeki en önemli gelişmedir (Avcı, 2004: 327). Emevi'lerin ardından 750 yılı sonrası Abbasi, 878 yılı sonrası Tolunoğulları (Yıldız, 1989: 142), 933 yılı sonrası İhşidîler, 969 yılı sonrası Fatımîler (Seyyid, 1995: 230), 1071 yılı sonrası 27 yıl süreyle Selçukluların süreli yönetiminde kalan Kudüs Şehri, XI. yüzyııın sonlarından itibaren yaklaşık 200 yıl süreyle Haçlı saldııılarının hedefi olmuştur.

1099 yılında Latin Krallığı'nın Filistin topraklarında kurulmasıyla, onların bölgedeki başkenti olarak kullanılan Kudüs Şehri, Selahaddin Eyyûbi tarafından 1187 senesinde fethedilene kadar Haçıı hâkimiyetinde kaldı (Demirkent, 2002 DiA: 330). Selahaddin'in 1193'te ölümüyle, Eyyubi Devleti'nin siyasi ve idari yapısında yaşanan olumsuzluklar Kudüs'ü etkiledi. Bu nedenle şehirdeki Türk-i̇slâm hâkimiyetinde bir süreliğine gevşeme yaşanmıştır. Ekim 1244'te Eyyubi Hükümdarı el-Melikü's-Sâlih, yardımını talep ettiği Harezmî Berke Han'la birlikte, Suriye Eyyubilerini ve onlarla ortak hareket eden Haçlılar'ı Gazze Savaşında mağlup edince Kudüs kesin olarak Eyyubilerin kontrolüne geçti. Böylece Haçlıların 1099 senesinde şehri ilk fethedişinin üzerinden 145 yıl geçmesinden sonra, Kudüs şehri Türk hâkimiyetine girdi. Haçlı Seferleri sürerken kısa süreli el değiştirmeler sonrası, 3 Eylül 1260 tarihinde Baybars'ın 43 senedir yenilemeyen Moğolları "Ayn-ı Câlût Savaşı”nda mağlup etmesinin ardından, Memluklerin Suriye-Filistin bölgesini kontrolleri altına almasıyla, Kudüs ve çevresi tamamen Müslüman toprağı haline geldi (Tomar, 2002 DiA: 333).

250 yıl süreyle Memlûklerin yönetimindeki Kudüs'te ara sıra zorluklar içerisinde yaşayan Fransiskenler ${ }^{2}$ (Tarakçı, 2009: 229) Memlûklerin son dönemlerinde daha rahat bir hayat yaşamaktaydı. Daha Yavuz'un şehzadeliği dönemindeyken 1506 yılında şehirdeki Katolikler için de yeni bir rahatlama sürecine girilmişti. O tarihlerde Fransa tahtında bulunan XII. Luis de Kudüs'e iki elçi göndererek, Kutsal Topraklardaki Katoliklerin kendi emanetinde bulunduğunu göstermiştir. Yavuz Sultan Selim'in Kudüs'ü alması sonrası Katoliklerin şehirdeki faaliyet anlamında rahatlığı zayıflayarak, daha çok Ortodoks Rumlar etkin olmaya başladılar. Öyle ki, Kudüs Rum Patriği, maddi varlık ve nüfuzlarını kiliselerinin emrine sunan İstanbul'daki Fener Rum Beylerine ${ }^{3}$ (Karpat, 2015: 359) bağlı bir görüntü içerisine girmiş görünmektedir (Türkan, 2013: 47).

Müslüman Türk'ün Anadolu'daki varlığının ilk dönemlerden itibaren başlayan haçlı seferleri, şüphesiz Ön Asya ve Ortadoğu'da hâkimiyet tesis etme gayretinde oldukları gerçeğinden hareketle Türk varlı̆̆ına karşı bir Hristiyanlık reaksiyonu ve topyekûn bir refleks olarak değerlendirilebilir. Bu anlamda Hristiyan Batı Kudüs'ü Müslümanlardan kurtarmak gibi anlatılan ama aslında Müslüman Türkleri Ön-Asya'dan atarak, yöredeki maddi imkânları kontrolüne almak için gelen askerlerin tamamına yakını Türk direnişi karşısında geri çekilmek mecburiyetinde kaldılar. Devlet yıkıp devlet kuran bu askerlerin başarısız olmaları sonrası, onların yerini bu kez de koloniler oluşturan ticaret erbabı ile kilise ve okul açan misyonerler almaya başladı. Kolonilerdeki bu yönelim şüphesiz Hristiyan Batının Ortadoğu’ya hâkim olma hedefine Kudüs üzerinden yürümesiyle gerçekleşecektir. Çünkü Kudüs'e hâkim olan gücün bütün bölgeyi kontrol altında tutacağı bilinmektedir (Aksoy, 2015: 31). İslâm toplumlarına hâkim olabilmek yanında kısmen bu düşüncenin de tesiriyle hareket eden I. Selim'in bölgeye yaptığı büyük sefer sırasında Memlukler'e karşı Mercidabık'ta kazandığı zaferde muhtemelen Kudüs şehri Ekim 1516'da Yavuz gelmeden Osmanlı yönetimine girmişti (Ercan, 1988; s. 10).

Müslümanlar Kudüs konusunda üç önemli fatih bulunduğuna inanırlar. Bunlardan ilki 638 yılında Hz. Ömer; ikincisi, 02 Ekim 1187'de Selahaddin Eyyubi ve sonuncusu da Ekim 1516'da Yavuz Sultan Selim'dir. Bu anlamda bakıldığında konu ile ilgili, kroniklerde Kudüs için önem arz eden şahsiyetler arasındaki bağlantılar ve benzetmelere de sıkça rastlamak mümkün olmaktadır. Mesela Naima; Selahaddin Eyyubi ile Yavuz Sultan Selim arasındaki liderlik vasıflarına dikkat çektikten sonra, devletin düzenli bir tarzda yönetilmesi halinde devam edeceğine işaret etmiştir. Bu intizam ve sistemin en büyük örneği olarak Selahaddin Eyyubi gösterilmektedir. Zira haçlıların elinde bulunan Şam beldeleri Eyyubilerin sistemli devlet yapıları sayesinde Haçlılardan kurtulmuştur. Selahaddin Eyyûbî Kudüs ve civarını Haçlılardan almadan önce musahipliğini yaptığı Ebü’n-necib adındaki birinin kendisine verdiği “tedbir-i memleket ve

\footnotetext{
${ }^{2}$ Tarakçı'nın Felsefe Ansiklopedisi'ndeki ifadesine göre, Fransisken ve Dominiken Tarikatları, geçimlerini halkın verdiği sadakalarla sağlayan Hristiyan gezgin dilenci vaiz tarikatlarıdır.

${ }^{3}$ Fenerli Beyler diye anılan azınlıklar, Osmanlı Devleti’nin önemli makamlarında uzun süre görev alan Rumlardır. Özellikle XVıII. yüzyılın sonlarından itibaren Rumların kilise düzeniyle eğitimlerinde önemli etkileri olmuştur. Osmanlıda yaşamalarına rağmen batı toplumunu model alan Fenerli Beyler, Rum cemaatinde bir takım değişiklikler de istemişlerdir. Bunun yanında Slav ve Lehleri toplumlarını da Rumlaştırmaya çalışmışlardır. Kemal H. Karpat, “Osmanlı'da Değişim, Modernleşme ve Uluslaşma", Çev. Dilek Özdemir, s. 359, İmge Yayınevi, Ankara, 2006
} 
esrar-ı saltanat" (Ayverdi, 1999: 259) konulu risaledeki uyarılar doğrultusunda hareket etmesinin sonucunda saltanat sahibi olduktan sonra Kudüs'ü de fethetmiştir. Bahse konu bu risale Kudüs'ün Yavuz Sultan Selim tarafından fethedildiği hicri 922 senesinde (1516-1517) Müeyyed Abdürrahim Efendiye ulaşmıştır. Abdürrahim Efendi ise Seyyid Ahmed el-Buhari hazretleriyle sohbetleri sırasında Şehzâde Selim'e bu risalenin ulaştırılmasını isteyince, Buhari vasıtasıyla Abdürrahim Efendi Şehzâde Selim ile buluşturulup bu risaleyi Türk Sultanına sunmuştur. Naima naklettiği bu kıssa ile Yavuz Sultan Selim'in saltanat sırrında ve Kudüs'ü fethinde görülen maddi ve manevi sırlarda, Selahaddin Eyyubi'ye de bir pay çıkarmaya çalışmaktadır. Bu aktarımlar yoluyla, Yavuz Sultan Selim'in Memluklerden Kudüs'ü almasıyla Selahaddin Eyyubi'nin Haçılırdan alması arasında bulunan bağa vurguda bulunmuştur. Buradan çıkarılan sonuca göre de Yavuz Sultan Selim Han'ın Müslüman bir devlete karşı yaptığı savaşın geçerli bir sebebe dayandırılmaya çalışılmıştır. Bu anlatılan bilgilerin tarihçilere de yansıması gayet doğaldır Ayrıca. Yavuz Sultan Selim ile birlikte sefere katılmış olan İdris-i Bitlisî'nin de Memluklere olan karşıtlığı açık şekilde yansımaktadır (Dolu, 2016: 21-46).

Yine bu doğrultuda Yavuz'un Mısır seferindeki başarısıyla beraber i̇slâm Dünyasında "Hâdimü'l Haremeyni'şŞerifeyn" unvanıyla (H. Yavuz, 2003; CC) anılması sonrası Türk Cihan Devletinin Sultanları bütün İslam Dünyasında ün kazandılar. Bu unvan $\mathrm{Hz}$. Ömer zamanından itibaren verilen bir ferman olarak bilinmekte iken kullanılmamış ama Yavuz'dan sonraki Osmanlı padişahları tarafından tekrarlanmıştır (A.DVN. KLS. d, 08/7).

Birinci Selim hayranları arasında olup, O'nun açıkça taraftarlığını yapan Celâl-zâde'nin O'nu Kudüs şâhı olarak ilan etmesine de şaşırmamak lazımdır. Yavuz'un Kudüs'ün şâhı unvanı Celâl-zade de Mekke ve Medine hizmetiyle beraber yer almaktadır (Celal-zade, 1990: 249). Bu itibarı tabii ki sadece Yavuz ve Kanuni ile sınırlandıramayız. Ahmed Câvid'in ifade ettiği şekliyle III. Selim'in de kendisini şöyle tavsif ettiği belirtilmektedir: "Mekke ve Medine Haremleri, Mescid-i Aksâ ve Kudüs-i şerîf mübârekin hâdimi ve hâkimi.........es-Sultân Selim Han....." (Cavid. 1998; 82).

\section{Osmanlı Döneminde Kudüs}

Osmanlı Türk Cihan Devleti Yavuz'un fethinden itibaren 401 yıl süreyle Filistin ve yakınındaki bu toprakların tamamında egemen oldu. Filistin; Müslüman, Hristiyan ve Yahudi inanca sahip olan tün insanlar için büyük önem verilen bölge olma özelliğini daima korudu. Doğu Roma İmparatorluğunun hâkimiyeti altındaki dönemlerde olduğu gibi yine bu dönemde, bölgede mevcut Hristiyanlığın çeşitli mezhepleri daima birbirleriyle çatışma hâlindeydiler. Osmanlı Türk Cihan Devleti bölgeyi fethetmesinden sonra Filistin bölgesinde idari anlamda özel bir yöntem uyguladı. Özellikle Avrupa'da yaygın olan Hristiyanlığın geleneksel Yahudi düşmanlığı anlayışı takıntısından uzak mesafedeki insanların tamamında olduğu gibi, Yahudi inancındakilerin tarih boyu yeryüzünde en huzurlu ve özgür yaşadıkları topraklar Osmanlı ülkesi olmuştur. Tarihlerinin en eski dönemlerinden beri Yahudiler, XIX. asır Avrupa'sında, bir kurumsal hizmetine girebilmekten mahrum olmaları yanında, din ve tapınma özgürlüğü ve hatta yaşam hakkından bile mahrum olmaları yanında, getto denilen mahallelerde çok ağır ve olumsuz şartlarda yaşarlardı. Mal-mülke sahip olabilme, eğitim-öğretim, yolculuk yapabilme, matbaa kurup eserlerini basabilme, gazete çıkarma hakkına bile sahip olamadılar. Onların en serbest yaşayabildikleri ülkelerden biri olan Avusturya'da Yahudilere, bir beldeye yerleşebilme, bir kısım sanatları yapma ve Cizvit üniversiteleri dışındaki üniversitelere gidebilme hakkı, ancak 1789 ihtilâlinin sıkıntıları sebebiyle, ancak 1792 tolerans beratı sayesinde tanınmıştır. Bu tür kısıtlamaları Osmanlı Türk Cihan Devleti hiçbir azınlık için asla uygulamadığı gibi, aklından bile bile geçirmedi (Ekinci, 2010: 3).

Osmanlı Devleti'nin yönetimine geçmesinden sonra Kudüs, hususiyetle Kanuni Sultan Süleyman döneminde en rahat ve huzurlu günlerini yaşamıştır. Kanuni devrinde gerçekleştirilen yenileştirme ve imar faaliyetlerine, Kubbetü'sSahra'nın restorasyonuyla başlanıldı. Onun döneminde Bizans Devleti zamanında yapılan surlara ilaveten, bugün hala ayakta olan surların inşası gerçekleştirildi. Bu surların yapımının beş yılda tamamlanması yanında surların 3 kilometreyi bulan uzunluğu ile 12 metreyi aşan yüksekliği dikkat çekicidir. Aynı zamanda 34 kulesi ve 7 farklı yerde kapısı mevcuttur. Bu kapılardan bir tanesi dışında kalanların üzerinde yapıldıkları tarihi gösteren kitabeler bulunmaktadır (Dolu, 2016: 38).

I. Süleyman tarafından Kudüs ile ilgili olarak hazırlanan bir başka proje ise, Roma İmparatorluğu döneminden kalan ve Beytüllahm ile Halilü'r-rahman dağlarından Kudüs'e su getiren su kanallarındaki hasarın tamir edildi. Ayrıca Kudüs şehrine su dağııımında suları toplayan havuzların yenilenmesi yanında, sur içinde bulunan beş çeşme ile beraber toplam altı çeşme şehre kazandırıldı. Osmanlı Sultanları ve devlet erkânı, Kudüs'te çok sayıda çeşme, hayrat ve şadırvan yaptılar, yıpranmış olanları da tamir ettirerek şehri mamur ve daha cazip bir şekle getirdiler. Kudüs Şer'iyye Sicillerindeki ifadelerden anlaşıldığına göre, Memlukler döneminde bir "taş medeniyeti" haline getirilmiş iken, Osmanlılar Cihan Devleti zamanında "su medeniyeti" ne dönüştürülmüştü. Bu arada şehrin imarını kolaylaştırmak için kurulan vakıflar aracılığıyla Kudüs'te görüntüye hoş gelen büyük farklılıklar meydana getirilmiştir (Köse, 2015: 161)

(Kastamonu Eğitim Dergisi, 28(2), 2020) 
Osmanlı Sultanları Kudüs’teki birçok kutsal değeri haiz alanı onarırlar ya da yenilerini inşa ederlerken, eserlerinin duvarlarına hizmetlerini ifade eden beyannameleri de nakşetmeyi ihmal etmemişlerdir. Bu eserlerden en eskisi 1524 yılında I. Süleyman dönemine ait olan, Hz. İsa peygamberin yardımcılarıyla yediği son akşam yemeğini, aynı zamanda Hz. Davud Peygamber'in mezarının bulunduğu ve sonradan camiye çevrilen Sion kapısındaki Coenaculum'un duvarında bulunan kitabede görülen “Beytü'l-harem'in hizmetçisi, İslâm'ın koruyucusu Sultan Süleyman'ın emriyle bu yerin müşriklerden temizlenmesi ve onun içinde bir mescit yapılması emredildi" ifadesidir (Dolu, 2016: 34). İşte bu cümle Kanuni'nin şehir üzerindeki iktidarının net bir göstergesidir. Ancak bu cümle, Yafa kapısındaki bulunan ve bütün halkı kucaklayan kitabeye ters düşse de Osmanlı padişahlarına "İslâm hukukundaki fetih hakkı" nın, ele geçirdikleri yörelerde mevcut ibadethaneleri düzenlenme yetkisi tanımakta olduğunu gösterir.

Osmanlı Devleti'nin yaşadığı duraklama ve gerileme dönemlerindeki durum Kudüs'te de olumsuzluklara sebep olmuş, eğitim-sağlık başta olmak üzere çeşitli kurum ve vakıflarda etkisini açık bir şekilde hissettirmiştir. Farklı devletler tarafından Kudüs'te XIX. asırda konsolosluklar açılması, Batılı Ülkelerin Kudüs'te üstünlük rekabetine girmelerine zemin hazırlamıştır. Bu gelişme Yahudilerin XIX. yüzyıl ve devamında art arda gelişen hicretleri paralelinde Kudüs'ün demografik durumunu büyük bir şekilde etkilemiştir. Bu değişiklik toplumun sosyal yapısıyla, eğitim-din-sağlık gibi alanlara da intikal etmiştir (Köse, 2015: 161).

XVII ve XVIII. yüzyıllarda gelişen ve Fransız ihtilali sonrası Osmanlı Cihan Devleti topraklarında etkili olmaya başlayan milliyetçilik hareketlenmesine karşı başlatılan bir "Osmanlılaşma” (Cohen, 2017: 3) kavramı ile Osmanlı merkezî hükümeti, halkıyla arasındaki yeniden yapılanmayı tesis etmeye çalışmaktaydı. Bu durum Kudüs'te yaşayanların, merkezi yönetimin kontrolünde bulunması sebebiyle sisteme uyarlanmış bir seçkinler sınıfı oluşmasına zemin hazırlamıştı. Diğer taraftan merkezi bürokrasiye mensup olanların yerelleşmesi açıkça hissedilmekte idi. Osmanlı Devlet yapılanmasındaki kurumsal çerçeveyle uyumlu hale getirilen taşralılar, bir taraftan üzerlerine uygulanan ılımlı ve müsamahakâr tüm yaklaşımları kendileri lehine değerlendirerek devlet şemsiyesi altında taşradaki güçlerini arttırıyorlar, diğer taraftan da Türk Cihan Devleti'nin tarihi derinliğe sahip örfi-idari yapısını da istedikleri şekle dönüştürüyorlardı. Gittikçe zayıflamakta olan Osmanlı merkezi idaresinin bu gelişmelere karşı, hem taşradaki kaynaklardan yönetimin yararlanmasını sağlamak ve hem de taşranın güvenliğini devam ettirmek için bu mahalli güçleri kendi bünyesinde toplamaktan başka çaresi yoktu. Bu gelişmelerde dikkat çeken şey; bu yeni uyum sağlama işlerinde uygulama yönteminin, "merkezden taşraya dikey bir atama süreci ile değil, daha ziyade müzakere ve uzlaşı üzerinden devam eden yatay bir süreçle oluşması” ile sağlanıyordu (Yaycıoğlu, 2010; 667-709).

Avrupa ve Osmanlı' daki bu gelişmeler sonucunda Yahudiler arasında Duvarcı Ustası dayanışması olan yapılanma, Theodor Herzl tarafından politik bir hareket haline dönüşmüş ve XIX. yüzyıl başlarında Siyonizm ifadesiyle konuşulmaya başlanmıştır. Siyonizm olarak isimlendirilen fikir, yüzlerce yıldır Yahudi ve Hristiyan düşüncesinin temsilcileri arasında karmaşalara sebep olan bir tartışma konusu halinde bugüne kadar süregelmiştir (Oğan, 1997: 8).

1882 yılında bir yolunu bulup Araplardan toprak satın alarak Filistin'e göç eden Yahudilerin dünyanın dört bir yanından Filistin'e gelmeleri ve siyasi olarak Siyonizm'e, başta Ingiltere ve Fransa gibi sömürgeci devletlerin destek vermesi hiç bitmeyecek bir Arap-İsrail çatışmasına sebep olmuştur. Theodor Herzl önderliğinde gelişen Siyonist hareket, Filistin coğrafyasına akın akın gelişen Yahudi göçü haline dönüşmüştür. Zaten bölgede yüzyıllardır var olan hareketliliğin böylelikle yeni boyutlara taşındığı görülür. Uluslararası kamuoyunda büyük devletlerin de Ortadoğu konusunda stratejik manevralar geliştirip uygulamaları Filistin sorununun devamını sağlamıştır (Tokgöz, 2001: 185).

Theodor Herzl olarak tanıdığımız Binyamin Ze'ev (1860-1904) 2 Mayıs 1860 tarihinde doğdu. Macaristan'ın Budapeşte şehrinde maddi durumu iyi olan Yahudi bir ailenin oğludur. Asimile olmuş bir aileden olan annesi tarafından, Alman-Yahudi örfü doğrultusunda eğitilmiştir. Ailesinin sonradan Viyana'ya göç etmesi yüzünden eğitimini hukuk ve ekonomi alanlarında yapmak zorunda kalmıştır. Siyonizm için hiçbir ilgi duymayan Herzl, adı Wilhelm Yensens olan bir Yahudi'ye ait "Köln'deki Yahudiler" adındaki kitabı okuyunca, Alman gettosunun Yahudi insanının inanç değerlerini darmadağın ettiğini anlayarak, İsrail oğulları ırkının değerlerini korumaya başlamıştır. Bu çerçevede Thedor Herzl, siyasi Siyonizm'in pasif olduğu bir dönemde lider olarak ortaya çıktı ve Avrupa'daki Rothschild, Baron Hirsch vs. gibi zengin Yahudi aileleri idealize ederek, Filistin topraklarının 'Arz-ı Mev'ûd' (vaad edilmiş topraklar) hedefi doğrultusunda kazanmaya çalıştı. Hatta "Judenstaat" (Yahudi Devleti) adlı broşürü Şubat 1896'da yayınlayarak, o gün için Yahudi sorununa modern bir çözüm bulmaya çalıştı. Sonraki dönemlerde bu eser Siyonizm'in önemli bir programı haline geldi. Herzl'in bu kitabı yayınlamadaki asıl gayesi, konunun dünya sorunu haline getirilmesiydi. Böylece O’nun sayesinde Siyonizm, Yahudilerin milli dünya görüşü haline getirmiştir. Bunu takiben Kadıma ve Siyon gibi öncü cemiyetler Herzl'e Siyonizm'in liderliği çağrısında bulunmuşlardır. Doğu Avrupa ve Polonya'da orta sınıf durumunda olan Yahudilerin Filistin'de işçiler olarak 1904 yılında başlattıkları hareket, Gomel Grubu'nun gelmesiyle birlikte anlam kazanmıştır (Türk, 2007: 82). 


\section{Farklı İnançların Kudüs'ündeki Gelişmeler}

İnançlar arası kutsal olarak kabul gören Kudüs şehri, günümüzde bütün dünyanın ilgi odağı olduğu gibi tarihin derinliklerinde de Müslüman, Yahudi ve Hristiyan dünyasında aralıksız olarak güç gösterilerine ve etkin olma rekabetine sahne olmuştur. Bu gerekçeyle tarih boyunca bütün dikkatler Kudüs üzerinde yoğunlaşmıştır. Farkı inançlara sahip olanların kutsallık atfettikleri Kudüs'te yönetimin sahibi olmak daima bir hedef olmuştur. Bu büyük ideali gerçekleştirebilmek için çeşitli uygulamalar ortaya koymuşlardır. Günümüzde Kudüs ve çevresinde yaşananları tarihi geçmişten ayrı bir tarzda değerlendirmek bizi hedefimizden saptırmakla kalmayıp, doğru bir tespite ulaşmamıza da engel olacaktır. Bu bağlamda zamanımızın Filistin'inde yaşanan olayları isabetli değerlendirebilmek için bölgenin tarihin derinliklerinde yaşadığı olayları iyi tahlil etmek gerekir. Kudüs adına rastlanılan en eski belge milâttan önce XIX veXVIII. yüzyıllara ait Mısır yazıtlarıdır (IDB, II, 843; EJd., IX, 1379). İsa'dan önce XIV. yüzyıla ait "Tell Amarna" denilen mektuplarda şehrin adı Urusalim, Eski Asur yazıtlarında Urusilimmu veya Ursalimmu, İbrânî dili Masoretik yazıtlarda Yruşlm, veya Yruşlym biçiminde yazılmaktaydı. Yerûşâlayim, ise Eski Ahid'in Ârâmîce yazılı olan eserlerde Yerûşâlêm şeklinde kaydedilmiştir. Grekçe Hierosolyma adı şehrin kutsallığını anlatmaktadır. Latince'ye ise Jerusalem ve Jerosolyma şeklinde geçmiştir. Kudüs'ün Avrupa dillerindeki adı da Jerusalem'dir (Harman, 2002: 26/324). Kamil Kepeci defterlerindeki (KK.d.) 0103, sayfa 21'de kayıtlı II. Murad dönemine ait ve 21 Ramazân 991/8 Ekim 1583 tarihli bir hüküm kaydına göre; "Kudüs-i Şerîf kādîsına hüküm ki: Ermeni tâifesinden dârendegân David ve ...? nâm zimmîler gelüp Kudüs-i Şerîf kurbunda Beytü'l-Lahm nâm mahalde Ermeni tâyifesi iki kandîl yaka gelmişler iken hâlâ ifrenc tâyifesi biz yakarız deyü mâni' oldukların bildürdükleri ecilden kadîmden olıgelen ile 'amel olunmak emr idüp buyurdum ki kadîmden ne vecihle olınagelmiş ise girü ol vecihle 'amel ettürüp ifrenc tâifesine olıgelâna muhâlif iş ittiremeyesiz" şeklindeki ifadelerden, iki mezhep arasındaki anlaşmazlıklara vurgu yapılarak, çözüm için talimat gönderilmiştir.

Osmanlı döneminde ezici sayıdaki Müslüman çoğunluk yanında, Gayr-i Müslim halk için Ortodoks mezhebine mensup olanların sayıca fazla olduğu ama Kudüs Hristiyanları arasındaki mezhep farklılıklarının arasının da gergin bulunduğu görülmektedir. Özellikle Latin özel inancında olan Hristiyanlarla, Rum ve Ermeni kiliselerine bağlı olanlar tarafından kutsal kabul gören mekânlar konusundaki hakların kullanımı hususunda aralıksız tartışmalar olmuştur. Hatta bu problemler öylesine ileri safhalara ulaştı ki, 1660-1670 arasında, Latin inancındakilerle, Rum Ortodoks Hristiyanları arasında kanlı çatışmalara bile sebebiyet vermiştir. Bunun sebebi Ortodoksların sayıca kalabalık olmalarına karşın, Latinlere Avrupa Katoliklerinin destek vermeleri yüzünden sıkça gerginlikler olmuştur. Üstelik Fransız hükumetinin Latin kilisesi lehine faaliyetlerini ara vermeden sürdürmesi yanında Rum kilisesinin de XVIII. Yüzyıldan itibaren İstanbul merkez yönetimi üzerinde etkisini artırması sonucu Habeş, Süryanî ve Kıptîlerinin doğrudan hükümet merkezine bağlanmasının sağlaması gibi gelişmeler Hristiyan guruplar arasında mevcut anlaşmazlıkları daima ileri safhalara taşımıştır. Dönemin Tahrir defterleri bizlere, Hristiyan varlığının kendi içindeki dağıımına dair yeterli bilgiler vermektedir. Bu defterlerdeki kayıtlı bilgiler incelendiğinde Kudüs'te oturmakta olan Hristiyanların tamamına yakınının şehre doğudan gelerek yerleşmiş olduğu izlenimini ortaya çıkmaktadır. Şehrin değişik yerlerinde bazı kilise ve manastırları kurmuş olan Fransisken rahipler ise kente Avrupa'dan görevlendirme yoluyla gelmişlerdir. Bütün bu tespitlerden anlaşıldığına göre bu dönemde Kudüs'teki Katolik mevcudiyetin ve etkilerinin, diğer Hristiyan cemaatlere bakıldığında daha sınırlı olduğu kabul edilebilir (Öksüz, 2018: 28-29). XIX. yüzyııın son çeyreğinde Beytüllahim yöresinde Müslümanların 267, Rumların 980, Latinlerin 1884 ve Ermenilerin kişi olduğu tespit edilmiştir (COA, 667-46486).

Kudüs Rum Patrikhanesi yetkilileri, Rusya'nın Rumları yönetimi altına almaya çalıştığı süreçte özerkliğini kaybetmek istemedikleri için bu gelişmelere tepki gösterdi. Hatta Kudüs Rum Patriği 18 Mayıs 1895'te Osmanlı yetkililerine bir yazı göndererek, Rusların Kamame ${ }^{4}$ (Kıyamet) Kilisesi bitişiğinde bulunan bir binayı kilise ve manastıra çevirme gayretinde olmasını belirterek, mevcut durumu değiştirmeye çalıştığını şikâyet etmiştir. Patrik yazısının devamında buna müsaade edilmemesi gerektiğini, aksi takdirde devlet için çok büyük sıkıntılara yol açacağını dile getirmiştir (BOA, Y. PRK. BŞK, 41/38). 24 Şubat 1891 tarihli Konstantinopolis gazetesinin haberine göre ise İstanbul'daki

\footnotetext{
${ }^{4}$ Yaygın olarak Kıyamet ya da Kutsal Kabir Kilisesi olarak adlandırılan ama Müslümanların Kumame (çöplük) diyerek küçümsedikleri bu Şapelleriyle genişletilmiş yapı, aslında Hristiyanların tamamını ilgilendiren önemlidir. Kudüs ve havalisinde, Konstantin'in, Hristiyanlığı Roma İmparatorluğunun resmî dini ilan etmesini takiben Kudüs ve çevresinde başlatılan imar faaliyetleri sırasında yapımı sonrası sık müdahalelerle geçirdiği değişikliklerle günümüzde de ayaktadır. (Nebi BOZKURT, “Kubbetü'sSahra", TDV İslâm Ansiklopedisi, C. 26, Ankara 2000, s.306"). Hristiyanlarca aziz kabul edilenlerin yanında, Kudüs kralları da bu kiliseye defnedilmiştir. (BOZKURT, agm., 305) Hristiyan geleneğinin temel anlatıları arasında yer alan Hz. İsa'nın çarmıha gerilmesi, öldürülmesi, dirilmesi gibi çok özel olayların geçtiği varsayılan ve ileride bu olayların devamının geçeceği zannedilen mekânlar üzerine inşa edilmiş olup tüm Hristiyanların sahiplenilmektedir. Halen de ayinlerin yapılışı, özel dinî semboller, eşyalar ve şapeller sebebiyle kavgaya tutuştuğu bir külliyedir. (BOZKURT, agm., 307) Sadece Kudüs'te yaşamakta olan halk ve ruhban değil, dünyanın her yerinden gelen farklı mezhep ve guruplara ait Hristiyanlar burada ibadet ederler. Özellikle Manevi huzur ve temizlenmeyle beraber, zafer, bereket, sağlık ve uzun ömür beklentileri yüzünden çıkılan hac yolculukları, ele aldığımız dönemde çok uzun ve sıkıntılara doluydu ki, bunu tamamlayıp ülkelerine dönenler birer kahraman gibi karşılanmaktaydılar. Hacı olduğu andan, "hacı” hitabını adından çok duyan Hristiyanlar, eskisinden daha itibarlı bir hayata yaşıyorlardı. Müslüman bir ülkede yaşıyor olsalar bile durum bundan farklı değildi. Ayrıca Hac ziyaretleri Kudüs ekonomisi için de çok büyük önem arz etmekteydi. Bu ziyaretler kilise için önemli olması açısından düzenli gelir kaynağıydı. Kamame Kilisesi, Hz. İsa'nın doğduğu yeri temsil eden Beytüllahim Köyündeki Yeniden Diriliş Kilisesiyle beraber, samimi Hristiyanları Kudüs'e çeken en önemli iki yerden biri olması dolayısıyla, rahiplerin hem dinî ve hem de dünyevî kazanç için de, gözleri gibi baktıkları bir yerdi.
} 
Rum Ortodoks Patriği, Kudüs Rum Ortodoks ruhbanı arasında devam edegelen ihtilafın ivedilikle bitirilmesi ve yeni bir patrik seçimi yapılması gerektiği konusundaki düşüncelerini belirtmiştir. Bunun dikkate alınmaması halinde İstanbul Rum Patrikliği tarafından Kudüs Patrikliğine doğrudan bir atama yapılacağı konusunda Kudüs Patriklik kaymakamlığına bir yazımın yazıldığı belirtilmektedir (Sabah gazetesi, 15 Receb 1308/24 Şubat 1891).

O dönemlerde de eski devirlerden gelen bir anlayışla, Hristiyanlık âleminin Batılı devletlerini yüksek oranda ilgilendiren mukaddes alanlar Meselesi'nde ilk önce Fransiskenler ve Rum Ortodokslarını yetkili kabul görüyordu. Katolik Hristiyan âleminin hepsinin nazarında, Kutsal Mezar'ın asıl bekçilerinin Fransiskenler olduğu ileri sürülüyordu. Bu Hristiyan tarikatının San Salvator Manastırı'na gelen bütün hacılarına iyi davranılıyordu. Onları günah çıkarma, akşam yemeği ile Kutsal Yerleri ziyarete hazırlama; devamında dini törenleri icra etme, Mukaddes Mezar Kilisesi'ni ziyaret ettirme işlemlerini tamamlayıp dönerlerken, hacı olanlara dini görevlerini icra ettiklerine dair belgelerini düzenleme yetkisi daima onların elindeydi. Bunun yanında Kutsal Mezar şövalyelerini atama yetkisi ile "Kudüs Kutsal Mezarının Yaldızlı Atlarını" vermek vazifesi de Fransiskenlere devredilmiş olup, belirtilen bu hakları kimse onların ellerinden almaya çalışmıyordu (Zinkeisen, 2011: 590).

Avrupa'dan gelen çeşitli kiliselere mensup hacı adayları, aynı zamanda Fransiskenlerin ibadet-hanelerinin finansmanında mühim bir rol oynayarak kurumların varlıklarının devamlılığında büyük ölçüde ekonomik girdiler sağlamışlardır (Öksüz, 2018: 29). Bölgenin mahalli sakinleriyle bir ilgilerinin bulunmamasına rağmen, ekonomik anlamda öncelikle Fransa, Venedik ve Habsburg'lardan her türlü desteği alan Katolikler, aldıkları bu desteğin verdiği güçle Kudüs'teki varlıklarını devam ettirdiler. Bunlar Avrupa'dan şehre gelen Hristiyan hacı adaylarının ritüellerini yerine getirmeleri konusunda öncelikle, çeşitli ihtiyaçların karşılanması noktasında bir rehber görevini yerine getirmişlerdir (Uğurlu, 2016: 105).

Başbakanlık Osmanlı Arşiv Belgelerindeki bilgilerden anlaşıldığı kadarıyla süregelen hal doğrultusunda bakıldığında, Kudüs'teki Latin Kilisesi'nin kuruluşunun ilk günlerinde, Fransa'nın çekimser oluşu konusundaki söylentilere rağmen, bu kiliseyle ilgili resmi ilişkilerin Fransa üzerinden yürütüldüğü anlaşılmaktadır. Bu doğrultudaki bilgiler bize Fransa'nın, Latin Patrikliği ile ilgili bazı konularda, Osmanlı Hükümetine baskı yaptığı ve Latinlerin lehine isteklerde bulunduğunu göstermektedir. Mesela; Fransız elçiliği aracılı̆̆ı ile “Kudüs'teki yerel yönetimde Katoliklerin bulunmayışının üzüntüyle karşılandığı" Osmanlı Hükümetine bildirilmiştir. Fransa'ya göre, Latinlerin daha önce Suriye'de sahip bulunduğu ayrıcalıklar nedeniyle yerel mecliste Latin temsilcilere de yer verilmesi gerekmekteydi (Uğurlu, 2016: 117). Çünkü Fransa Kudüs'teki Rum Patrikhanesine bağlı çalışan Rum temsilcilerin, Latinlere karşı önüne çıkarıldığı konusunu hazmedemeyip, bunu kabullenmeme gereğini duymasıydı (BOA, HR. SYS., 1768/23, 20 Haziran 1876).

Kudüs Bölgesindeki anlaşmazlıklar açısından bakıldığında Fransa kendi siyasi nüfuzunu; Katolikler, İngiltere Anglikan ve diğer reform kilisesi mensupları üzerinden savunmaya çalışırken, Kudüs'e gelen hacıların çoğunluğunu Ruslar oluşturması gerekçesiyle Ruslar kendi nüfuzlarını; Ortodokslar üzerinden ortaya koyma gayretinde olmuşlardır. Hatta Rusya'nın Roma Sefiri, Kahire konsolosu, Maarif nazarı, Bahr-ı Sefid Amirali gibi önemli memurlar da bu hacıların arasındaydı (Sabah, 2 Muharrem 1317/13 Mayıs 1899). Bahse konu olan çatışmaların en belirgin örneğini ise Kıyamet Kilisesi'nde hak talep eden Ortodoks ve Katoliklerin, sonradan Rusya-Fransa rekabetinin doğmasına sebep olmalarında görürüz (Türkan, 2004: 200). Bu gelişmelerin sonrasında Kırım Savaşı gibi büyük bir harbe yol açmış ve savaşın sonrasında imzalanan Paris Antlaşması ile Kudüs üzerinde uluslararası alanda Rusya'nın himaye talebi kabul edilmemiştir (Avcl, 2004: 68).

Anti-Semitist yaklaşımların etkisiyle Yahudi-Hristiyan ilişkileri, zorla din değiştirmelere varan kötü bir sicil yanında zaman zaman kanlı çatışmaların ötesinde katliamlara sahne olmuştur. Bütün bu olumsuzluklarla dolu geçmişe rağmen Yahudi-Hristiyanlar asırlar boyunca Kudüs'te Müslüman Türkler ve Arapların yönetiminde huzurla aynı mekânı paylaşmışlardır (Öksüz, 2004: 28). Kudüs şehrinde Hristiyan anlayışın hâkim bulunduğu dönemlerde, Yahudi olanların şehre ancak yılda bir defa girmelerine izin veriliyor ve Tapınak Tepesi adı verilen kutsal mekânı da yine bir kere ziyaret edebiliyorlardı (Buhl, 2004: 954). Özellikle Avrupa'nın Yahudilerle süregelen kinleşmeleri neticesinde bu insanlar, İngiltere'den 1290'da, Fransa'dan 1392'de, İspanya'dan 1492'de ve Portekiz'den de 1497 tarihinde çıkarıldılar Yahudilerden bazıları ise inançlarını gizleyerek, Hristiyan inancını kabullenmiş gibi davrandılar. 1600'lü yıllara girilirken sadece İspanya' da katledilen İsrail-oğullarının sayısı 100.000 rakamına ulaşmıştı.

Yaşadıkları bölgelerden kovulanların bazıları Hollanda'ya iltica ettilerse de büyük bir kısmı II. Bayezid Döneminde Osmanlı Devleti'nin himayesine sığındılar. Almanya'dan kovulanların büyük bir kısmı Polonya topraklarına gittiler (Kocabaş, 1987: 35-37). 1880'li yıllarda Doğu Avrupa'da başlayan antisemitik hareketler sebebiyle bölgeye ilk göç hareketinin gerçekleştiği görülmektedir. Bu ilk hareketlenmenin ardından bölgeye başka göçler de gerçekleşmiş ise de 
bunlar pek ilgi çekmemiş ve Yahudi grupların Eretz Israel terimiyle ifade edilen ve Yahudiler için eski bir manevi anlam ifade eden bir düşünceyle bölgeye gelişleri şeklinde yorumlanmıştır. Bu göçler görünüşte, ecdad toprakları veya Tanrının kendilerine vadettiği topraklara dönüş mesajı verse de asıl temayla dini bir bağ kurulduğunda seküler bir Yahudi eğilimi olan Siyonizm daha belirgin hale gelmektedir (Memiç, 2010: 21). Üstelik bu durum 1917 senesinde İngiltere'nin bölgede bir manda yönetimi kurması ile tamamen gerçek hedefi netleştiren bir gelişme göstermiştir. Çünkü İngiltere Dışişleri Bakanının Yahudi bir bankere yazdığı, İngilizler bölgeyi ele geçirdiklerinde şehri teslim alırken okuttukları 'Filistin'de Yahudilere yurt kurulması'nı onaylayan ve Balfour Bildirisi olarak bilinen bir mektup bulunmaktadır. Daha sonraki süreçte Yahudilerin Tevrat'ında mevcut ifadeler doğrultusunda, şehrin mukaddesatına karşı lazım olan hürmetin gösterileceğini duyurmuşlardır. Otuz sene zarfında bir yandan Araplar topluluklar içinde Yahudiler tarafından Kudüs'ün alınacağı ve Mescid-i Aksa'nın yıkılacağı konusundaki dedikodular yayılırken, öbür yandan da dindar Yahudiler, Batı Duvarı çevresinde ibadet etme isteklerini ifade etmeye başlamışlardır (Küçük, 1992: 101). Olaylar böyle devam etmekteyken Filistin'e Yahudi hicreti de artarak sürmüştür. Bu gelişmelerin tamamı Yahudilerle bölgede yaşayan Müslümanlar ve hatta Hristiyanlar arasında çatışmalara sebep olmuştur. Konuyu bu hale getiren İngilizler devam eden çatışmalardan yorulunca ve sorunun çözümünü Birleşmiş Milletler konseyine bırakmak zorunda kalmış ve bölgeden ayrılmışlardır (Nicault, 2001: 31).

Hristiyanlık bu bölgede ortaya çıksa da İsrail Hristiyanları birçok konuda dünyanın diğer bölgelerinde yaşayan dindaşlarıyla ters düşmeleri yüzünden İsrail vatandaşı Hristiyanların önemli bir miktarı İsrail Devleti'nin kuruluşundan itibaren azalmaya devam ediyor ${ }^{5}$.

Şüphesiz İsrail topraklarında Yahudilik çok önemli bir sosyal güce sahiptir. Yöredeki vuruşmalar ve İsrail'in bitmek bilmeyen yayılma politikaları hiç tereddütsüz dini inanç taassubundan kaynaklanmaktadır. Bu taassuba rağmen İsrail'in kurucuları Laik batı kültürünün temsilcileri gibi davranırlar.

Gerçekte Müslüman dünya için de Hicaz'dan sonra en mukaddes mekân İsrail ve buradaki Kudüs Şehridir. Bu anlayış üç değişik inancın sahipleri için' de geçerlidir. Yani Hristiyanların ve Yahudilerin de en kutsal mekânları tamamen İsrail Devletinin sıkı kontrolü altındadır.

Karen Armstrong gibi Kudüs konusunda araştırma yapan Avrupalılar, konuyla ilgili taraflar arasındaki Kudüs probleminde iki tarafın mevcudiyetini vurgular. Bu konuda net bir ifadeyle Hristiyan dünyasının Kudüs üzerindeki kutsallık söylemlerinin günümüzle ilgili olmayıp, tamamen 'ölüm ötesi hayatla ilgili' bulunduğunu, Kudüs ve Süleyman Mabedi hakkındaki konuların Hristiyan dünyasını şu an itibariyle ilgilendirmediğini ileri sürmektedirler. Günümüz açısından bakıldığında Batı Hristiyanlık âlemi şimdiki görüntüsüyle İsrail yanında yer alan bir tutum sergilese de Haçlı seferlerini yaptıkları dönemde olduğu bir hırsla Kudüs'ü ön plânda tutmamaktadırlar. Bu, Hristiyan dünyasının Kudüs ve onun kutsallığı iddialarından vazgeçti mesajı vermeye gayret etmektedir. Eğer durum böyle ise, bugüne kadar tarihi veriler ışığında Kudüs toprağında ölmek için akın akın yöreye gelme gayretini taşıyan yüzbinlerce insanın canı ve kıymeti ölçülemeyen malın telefine sebep olan Haçılır kimlerdi? Kudüs'e ulaşamayanlar adına Kudüs'ten getirilen toprağın serpildiği Prag'ın 70 km. doğusundaki Çek Cumhuriyeti'nin ikinci büyük şehri olan Kutna Hora'daki Sedlec Ossuary'ye defnedilen çok sayıda Hristiyan neyin peşindeydiler? Eğer bütün ümit ve istekleri ölüm ötesi hayatın kutsallığıyla ilgiliyse, neden hâlâ Kudüs Hristiyanlar için haccettikleri bir alandır?

Hususi anlamda Haçılır ve Tapınakçıların, genelde ise bütün Hristiyanlık âleminin bu kutsal şehir ile bağı kolaylıkla bitecek bir görünüm arz etmemektedir. Durum şu an için değerlendirildiğinde, sanki ilgisiz davranmalarını gerektiren sebeplerden birisi İsrail halkı ve devletinin Hristiyanlara ait kutsal alanlar üzerinde açıktan talepte bulunmaması ve Hristiyanlık âlemini bu doğrultuda rahatsız etmemesinden kaynaklanmaktadır. Diğer bir konu ise İsrail Devleti, Yahudi tarihine ait Kral Davud ve Süleyman Peygamber gibi isimlere ait mekânların kullanımı noktasında batılılara benzer değişik düşünceler içine girmemiştir. Aslında kavga konusu yapılan mekânlar Hz. İsa'nın gelişinden öncesi döneme ait olan alanlardır. Hristiyanlar tarafından sonradan inşa edilen mekânlardan olan Kıyamet Kilisesi gibi yerler ise Hristiyanların kendi aralarında tartışmalara sebep olan alanlardır (Batuk/Mert, 2017: 134).

Sultan Selahaddin'in Kudüs'ü almasına kadar Haçlılar Kudüs'te diğer inanç sahiplerinin bulunmasına izin vermemişlerdir. Müslümanların yeniden şehre hâkim oluşuyla beraber farklı inançtaki insanların tekrar birlikte yaşamalarına zemin hazırlanmıştır (Öke, 1981: 140). 19. Yüzyıla gelindiğinde yaşanan bazı siyasi sebeplerle Sultan II. Abdülhamid, Yahudilerin Filistin'i yurt edinmelerini engellemek düşüncesiyle 1883 ve 1891 de çıkardığı kanunlarla bölgede Yahudilere arazi devrini engellemiştir. Bu yüzden Tanrı'nın kendilerine vadettiğine inandıkları bu topraklara hukuki usullerle elde edemeyeceklerini kabullenen Yahudiler, kurdukları şirketler aracılığıyla toprakları elde etme 
metodunu uygulamışlarsa da Türk Devleti bu girişimlere de izin vermemek için, Yahudilere Kudüs'te toprak satışını yasaklayan kararlar uygulamıştır (Umar, 2002: 436; Karaman, 1996: 93).

\section{Kudüs'te İdari ve Sosyal Statü}

Filistin bölgesi tarih boyunca dünya kamuoyunu meşgul etmiş ve Kur'an da bahse konu olan karmaşa olaylarının yoğun biçimde cereyan ettiği bir belde olmuş ve devamında Müslüman, Yahudi ve Hristiyanlar arasında aralıksız hâkimiyet noktasında meydana gelen çatışmalar nedeniyle gerilimli bir nokta olmaktan bir türlü kurtulamamıştır. Her üç inanışın mensuplarınca kutsal kabul edilen bu şehirde egemen olmak bir nihai hedef haline gelmiş ve bu hedefe varabilmek için her türlü plan ve projeler hayata geçirilmiştir. Ortadoğu'da halen karşılaşılanları tarihi geçmişten ayrı yapacağımız değerlendirme, sonuç konusunda bizi doğru bir tespite ulaştıramaz. En azından doğru bir sonuç almamıza engel olur. Öyleyse günümüz Filistin'indeki olayları doğru yorumlayabilmek için yörenin geçmişini iyi tahlil etmemiz gerekir.

Bu çalışmanın kapsamının Osmanlı Devleti ile sınırlı olduğu noktasından hareketle, Cihan Devleti'nin taşrada uyguladığı teşkilat düzeniyle ilgili değerlendirmelerde bulunacağız. Bölgedeki mevcut teşkilat düzeni Şam beldelerinin alınmasından sonra, değiştirilmeden aynıyla icra edilerek (Çakar, 2003: 352), Kudüs ve çevresinin hâkimiyet altına alınması sonrası, idari yapıdaki uygulamalar değiştirilmemiş olup, sadece mülkî idare taksimatında "velâye" ifadesi kullanılmaya başlamıştır (Hitti, 1995: 1177). Kudüs Osmanlı Devleti'nde, Gazze, Nablus ve Safed şehirleriyle beraber yönetim bakımından Şam eyaletine içerisinde kalan sancaklar halinde ifade edilmiş ve Arz-ı Filistin adıyla anılmaya başlanmıştır (Karaman, 1996: 92). Bundan sonrasındaki Osmanlı Kudüs'ü, uzun süreçte aralık verilmeksizin sancak olarak kalmış, zaman zaman bağlı olduğu merkez değişmiş olsa da 1516-1831 yılları arasında Şam eyaletine bağlıydı (Aseli, 2002: 335).

Yavuz'un Mısır seferi dönüşü 15 Şubat 1518 tarihinde Orta Filistin'i içine alan Kudüs sancağının bağlı olduğu Şam Eyaleti Beylerbeyliği ise Canberdi Gazali'ye verildi (Emecen, 1993: 142). iki yıl sonra gerçekleşen Canberdi Gazali ayaklanması, Kudüs Şehri ile çevresini önemli ölçüde etkilemese de (Emecen, 1993:142) tedbir olarak bölgede bazı değişikliklerin yapılmasına sebep oldu ve Kudüs, Gazze ve Safed şehirleri Şam'dan ayrıldı. Bu şehirlerin başına merkezden sancakbeyleri atanarak Suriye' de yeni bir sistem oluşturuldu (Çakar, 2003: 373). Yeniden başlayan Osmanlı hâkimiyetinde Kudüs'ün daha istikrarlı bir yönetime kavuşmasıyla, Hilâlin Haç’a karşı süregelen mücadelesinin simgesi konumundaki Kudüs'te Hristiyanlık tehdidinin yok olmasıyla beraber şehrin politik anlamda önemi kalmadı (Tomar, 2002 DiA: 333).

1821 senesinde vuku bulan Yunan isyanı, Filistin civarındaki Ortodoks Rumlar arasında kımıldanmalara sebep olsa da, yetkililerin ciddi girişimleriyle çatışmalar önlendi. Bu doğrultuda 1825 senesinde gelişen Osmanlı yönetimindeki sıkıntılar paralelinde bölgede oluşan boşluktan faydalanmak isteyen Kudüs'e bağlı bazı köylerdeki yerli ahali askerlik yapmamak ve vergi vermemek gayesiyle ayaklanma başlatılmışsa da Remle-Kudüs bölgelerinde güçlü Arap şeyhi İbrâhim Ebû Goş'un da yardımlarıyla 1826'da kontrol yeniden sağlandı (Aseli, 2002: 336).

Kavalalı Mehmed Ali Paşa'nın 1831-1840 yılları arasındaki Mısır Valiliği sonrasında tekrar Osmanlı Devleti'nin yönetimine geçen Kudüs Şehrinde, O'nun sert uygulamaları rahatsızlıklara sebep olduktan sonra (Altındağ, 1945: 54). 1834-1838 yılları arasında Kudüs merkezli ayaklanmalar yaşandı. Aralık 1840'ta Osmanlı Devleti Kudüs'te kontrolü tekrar sağladı. 1841-1865 yılları arasında Sayda eyaleti ve yine aynı dönemde Sayda ve Şam Eyaletleri birleştirilerek Suriye vilayeti içinde yer aldı. 1872'den itibaren 1917 senesine kadar geçen sürede ise bölge bağımsız mutasarrıfık statüsünde merkezi hükümete bağlandı. Ekonomik konularda ise önce Halep'e bağlı iken, 1860 ortalarından itibaren 7 yıl müddetle Şam defterdarlığına bağlandı (Aseli, 2002: 335). 1873'ten sonrasında ise bağımsız bir sancak olan şehrin valisi İstanbul Hükumetine doğrudan bağlıydı (Nicault, 2001: 190).

1838 senesinde Misyoner faaliyetlerinin de hız kazandığı bir sürecin tetikleyicisi olan İngiltere, Kudüs'teki ilk konsolosluğu faaliyete soktu; onun ardından Avusturya, Rusya, Prusya konsolosluklarının açılışı gerçekleşti. Bu dönemde ayrıca Ingiliz-Alman Protestan piskoposluğu 1841 tarihinde kuruldu, 1845'te ise bunu Yunan-Ortodoks patrikliğinin İstanbul'dan Kudüs'e taşınması takip etti ve Latin patrikliği 1847'de yeniden harekete geçirildi.

Yukarıda da ifade ettiğimiz gibi XIX. Yüzyılın ilk yarısında bir süre kapalı kalan Kudüs Latin Patrikliği, Osmanlı Devleti'nin, Papalık ile olan münasebetlerindeki iyileşmeler paralelinde 1847 yılında tekrar faaliyetine başlamıştır. Latin Patrikliğinin faaliyetlerine yeniden başlamasında Fransa'nın etkisi açıkça görülse de Papalık, Fransa'nın bu etkisinden rahatsız olmakla, Osmanlı Devleti ile gayrı resmi yollardan görüşme çareleri aramıştır. Hatta bir dönem Kudüs Latin Patriği, Fransa'nın tasallutundan kurtulmak için Osmanlı Devleti tebaası olan diğer gayr-i Müslimler gibi bir statüye tabi tutulmayı talep etmiştir. Fakat bu talepte, Fransa'nın baskıları yüzünden olumlu bir neticeye varılamamıştır. Rusya ise 
Kudüs'te dini ve siyasi nüfuzuyla, bir taraftan Moskova Patrikliğine bağlı olarak kurumlarını geliştirirken diğer taraftan da Kudüs'teki Rum Ortodoksları da ihmal etmeyip, onlar üzerindeki nüfuzunu arttırmaya gayret etmiştir. İşte bu gayret doğrultusunda, Rusya'nın çabalarıyla 1645 senesi sonrasında İstanbul'da oturan Kudüs Rum Patrikliği 1845 senesinden itibaren Kudüs şehrine taşınmıştır (Satış, 2015:686-687). Rusya Kudüs'teki Ortodoks Rumlar üzerinde de tesirli olabilmek için, onların patrik seçiminde de etkin olma girişimlerini ihmal etmemiştir (BOA, Y. PRK. BŞK, 41/38).

Kudüs Rum Patrikhanesi için vuku bulan çatışmalar, Osmanlı Devleti'ndeki sükûneti sağlama gayretlerini de olumsuz yönde etkilemiştir. Bu anlamda Patrikler tarafından alınan kararların uygulanması yönünde yaşanan sıkıntılar, Türk Devletinin huzur ve düzenini tehdit ettiğinden ortak bir uzlaşma zemini oluşturma yolunda Babıali'de yoğun mesailer sarf edilmiştir. Osmanlı Devleti'nin Tanzimat Fermanıyla tespit ettiği yeni politikanın sonucu olarak Kudüs'te de Genel, İdari ve Beledi meclisler oluşturuldu. İstanbul'da 1863 yılında çıkarılan özel bir fermanla Meclis-i Beledi kurulduktan sonra, Kudüs Şehri'nde de aynı tarz uygulanınca İstanbul'a benzer bir meclise sahip ikinci Osmanlı kenti haline geldi (Aseli, 2002: 336). Iş̧te bu Meclis kuruluşunu takip eden üç yıl sonrasında 1867 senesinde faaliyetlerine başladı. İşte bu Belediyenin kuruluşunun ilk yıllarında reisü'l-beledi olarak dokuz yıl süreyle reislik görevini Yusuf elHâlidî yürütmüştür. Bundan sonra geçen yaklaşık 45 yıl süreyle seçilen tüm belediye reisleri, Hâlidî, Huseynî, A'lâmî ve Dücânî ailelerine mensup idiler (Aseli, 2002: 337). 1880 senesine kadar Belediye Meclisine seçilen -mühendis, tabip, veteriner vb. seçkin 6 üyesi varken, bu tarihten sonra sayı 10'a yükselmişti. 1898 yılında 700 Müslüman, 300 Hristiyan, 200 Yahudi olmak üzere toplam 1200 kişiye oy verme hakkı tanıyan, seçmek ve seçilmek için vergi ödenmesini gerektiren bir seçim sistemi uygulanmaya başladıktan sonra, meclis üyeleri için dört yıllığına seçilme hakkı getirildi. Seçimlerin, seçilen üyeler arasından Belediye Meclisi'nin kendi başkanını, yani belediye reisini belirleyecek olan kişi ise Osmanlı Devleti tarafından atanan vali idi. Meclis üyelerinin kendi aralarından seçtikleri yeni Başkan'ın işte bu valilik makamından onay alması gerekiyordu (Nicault, 2001: 86).

Siyonizm'in teorisini kurup teşkilâtlandıran Herzl, bu hareketi tasarlama çalışmalarında, üzerine kuracağı bir öncü hareketi ve belli ölçüde siyasî bilinçlenmeye ulaşmış inanır bir kitleyi çevresinde hazır buldu. Tanınmış bir gazetenin muhabirliğini yaptığı sırada Paris'te izlediği ve bir Yahudi yüzbaşının casusluk suçlamasıyla yargılanarak mahkûm edildiği "Dreyfuss Davası" onu Yahudi toplumunun yaşadığı problemler üzerinde durmaya ve Musevilere ait bir devlet fikrini işlediği Der Judenstaat (1896) isimli kitabını yazmaya yönlendirdi. Bu davayı görevli olarak takibi sırasında, Avrupa'da her geçen gün biraz daha yaygınlaşan Yahudi aleyhtarlığı O'nu aşırı derecede rahatsız etti. Herzl'in, her yerde ekseriyetle toplumdan dışlanmış azınlıklar olarak yaşayan Yahudilerin, birlikte yaşadıkları ülkelerin toplumlarıyla kaynaşmasının asla mümkün olmadığı yargısından hareketle bu kitabını kaleme aldığı da bilinmektedir (Karaman, 1996: 13/92).

Osmanlı Sicil Kayıtlarından elde ettiğimiz bilgilere göre aynı süreçteki gelişmeleri takiben Kudüs ve çevresinde bir Yahudi yerleşim hareketliliği gözlenmekteydi (BDA, 2009: 255)

Der Judenstaat adlı kitap, Yahudi topluluklar arasında değişik görüşlerin ortaya çıkması ve tartışmalı bir başlangıca yol açsa da çok geçmeden başta Avrupa'da yaşayan Yahudilerin muhatap oldukları diasporadan "Va'd edilmiş Kutsal Topraklar"a dönüşleri ve sonrasında Filistin'de Kudüs merkezli bir Yahudi Devleti kurma hedefiyle sonuçlanacak olan Siyonist hareket için önemli bir başlangıç noktası oldu. Dünya Siyonist Teşkilâtı bu sonuca ulaşma düşüncesi kapsamında, Herzl'in gayretleri ve liderliğinde 29 Ağustos 1897' de Basel'de ilk Dünya Siyonist Kongresi'ni toplayarak teşkilatlanma sürecini başlattı. Theodor Herzı Dünya Siyonist Kongresinin toplanmasını sağladıktan sonra, Filistin'i bir Yahudi yurdu yapma gayesindeki bir komitenin başkanlığına getirildi (Kocabaş, 1991: 37). Tartışmalar sonunda kararlaştıılan Basel Programı, hareketin resmî sınırlarını şöyle belirledi: Siyonizm, tarihten gelen bir mirasla Yahudi toplumuna, Filistin'de insan hakları anlayışının teminatı altında bir yurt kurulmasını hedef almaktaydı. Kongrede alınan kararların sağlıklı bir sonuca ulaşması için kongre Filistin'de Yahudi çiftçi, esnaf ve tüccarının planlı bir şekilde yerleştirilmesi gerekmekteydi. Yahudiler halen yaşamakta oldukları ülkelerin mevcut yasalarına uygun biçimde birleşip, örgütlenmeleri yanında, Yahudi Milli ve Musevi Manevi duygu ve bilincinin kuvvetlendirilmesine özen gösterilmesi

\footnotetext{
${ }^{6}$ Yıldız Saray-ı Hümâyûnu Başkitâbet Dairesi

Beyrut Vilâyeti dâhilinde Safed Kasabası'nda bulunan ve Hayfa'ya gelen dört yüz kırk ecnebi Musevînin istidâları vechile tâbiiyet-i Devlet-i Aliyye'ye kabulleri istizânını hâvî resîde-i dest-i ta'zîm olan fî 20 Zilhicce sene 308 tarihli tezkire-i sâmiye-i Sadâret-penâhîleri manzûr-ı âlî oldu. Musevîlerin Kudüs civarında ictimâ ve iskân etmeleri ileride orada bir Musevî Hükûmeti teşkilini intâc edebileceği mülâbesesiyle kat'â caiz olmadıkdan başka zaten Memâlik-i Şahane arazi-i hâliyeden ma'dûd olmadığına ve medenî Avrupalıların memleketlerinden tard etdikleri ephâsın Memâlik-i Şahaneye kabulüne bir sebeb olmayıp hususuyla ortada bir Ermeni fesadı mevcud iken bu suret asla caizol amayacağına nazaran ne merkûmûnun ne de sair Musevîlerin kabul olunmayarak Amerika'da iskân etmek üzere geri gönderilmeleri zımnýnda ba'demâ ayrı ayrı ma'rûzâta hâcet kalmayacak suretde Meclis-i Vükelâca umumî bir karar ittihâzıyla bâ-mazbata arz u istizân-ı keyfiyet olunması muktezây-ı irâde-i seniyye-i cenâb-ı Hilâfet-penâhîden bulunmuş ve binâenaleyh tezkire-i sâmiye-i vekâlet-penâhîleri takımıyla iade edilmiş olmađın ol bâbda emr u fermân hazret-i veliyyü'l emrindir.

Fî 21 Zilhicce sene 308- Fî 15 Temmuz sene 307 / [27 Temmuz 1891] Ý. MMS, 123/5276 Serkâtib-i Hazret-i Şehriyârî Süreyya
} 
yanında, Siyonizm'in amacına erişebilmesi yolunda hükümetlerin onayının temini yolunda hazırlık çalışmalarına girişilmesine karar verdi (Öke, 2002: 38).

Kongre sonunda alınan kararlar doğrultusunda 'Basel Programı' açıklandı. Yayınlanan belgede, "... bu belge ile biz İsrail Devleti'nin kurulduğunu ilan ederiz" tarzında kayıtla (Karaman, 1992: 546), Filistin bölgesinde ilk defa bir Yahudi Devletinin kurulması ve Dünya Siyonizm Teşkilatı'nın bu amaca ulaşmak için aktif şekilde hayata geçirilmesi ifade ediliyordu.

I. Siyonist Kongresi sonrasında Filistin bölgesine düzenli bir göç akını başladı. Aslında 1897 tarihinden çok evvel, az sayıda Siyonist muhacir zaten bölgeye gelmeye başlamıştı. 1903 yılında, gelenlerin sayısı 25.000'e ulaşınca Sultan II. Abdülhamid Yahudilerin bölgeye gelmelerini ve arazi alımlarını önleyici kanunlar çıkarttı. Buna rağmen engellenemeyen bu hareketlilikte göçmenlerin büyük çoğunluğu Doğu Avrupa'dan gelmekteydi. Bu gelen göçmenler bölgedeki yarım milyona yakın Arap sakiniyle birlikte yaşamaya başladılar (Umar, 2002: 421). Bahse konu olan XX. yüzyılın başlarındaki Filistin, 1517'den sonrasında olduğu gibi yine Osmanlı Türk Cihan Devleti'nin bir parçasıydı. 1904 ila 1914 arasında 40 bin kişilik bir ikinci göçmen dalgası bölgeye geldi. 1917 yılında Osmanlı Devleti'nin hâkimiyeti sona erdiğinde Filistin bölgesindeki Yahudi nüfus 85 binin üzerindeydi (Armaoğlu, 1994: 10).

\section{Osmanlı Kudüs’ünde Eğitim ve Eğitim Kurumları}

Kudüs'te Osmanlı Devleti döneminde eğitim ve öğretim faaliyeti gösteren Müslümanlara ait kurumların tamamı Osmanlı Döneminde kurulmamıştır. Hatta daha evvel Memlukler Döneminde kurulan medreselerin sayı bakımından, Osmanlı Döneminde azaldığı söylenebilir. Örneğin XVII. yüzyılda Kudüs merkezinde Memluk Döneminden kalan 56 medreseye, Osmanlı Döneminde 40 Medrese daha eklenerek faaliyete geçirilmiştir. Aynı asrın son çeyreğinde ise Mescid-i Aksa çevresinde medreselere tahsis edilmiş 200 kadar oda bulunduğu tespit edilmiştir (El-Aseli, 2002: 339).

Bölgede bulunan okulların yapısına bakıldığında; yatılı okullar umumiyetle iki katlı binalardı. Bunların alt katlarında eğitim ve öğretim yapılırken, üst kat öğrenci ve öğretmenlerin kalabilecekleri kısım olarak düzenlenmişti. 1896 senesinde Kudüs Rüştiyesine 81 öğrenci kayıt yaptırmıştı. 104 öğrencinin kayıt olduğu üç ortaokul Hristiyanlar içindi ve bunlarda Rumlar Ermenilerle Latinler okuyorlardı. Bunların dışında temel eğitim veren dördüncü okulda 140 öğrenci okumaktaydı (Aslan, 2015: 96).

1672 yılında Kudüs ve Filistin bölgesine seyahatinden bahseden Evliya Çelebi, bu şehirde yedi tane Darü'l-hadis, on dört Kurra, kırk Sıbyan Mektebi ve yetmiş tekke bulunduğunu ifade etmiştir. Ciddi miktarda vakıf gelirleriyle faaliyetlerini sürdüren bu tekkelerin en önde gelenleri Abdulkadir Geylani, Seyyid Ahmed Bedevî, Sâdî, Rıfâî (Parmaksızoğlu, 1985:258) kurumları olduğu ifade edilmiştir.

Viyana Bozgunu sonrası XVII. yüzyıl sonlarından itibaren gelişen çözülme süreci tüm bölgelere sirayet ettiğinden, Kudüs Şehri de bu olumsuzluklardan nasibini almıştır. Artık Kudüs'teki XVIII. yüzyıl başlarından itibaren tüm hizmet kurumlarının gelir kaynağı olan vakıfların sadece gelirleri değil, sayıları da azalmıs, esnaf ve sanatkârların da pek çoğu Asitane'ye göç edince ilim kurumları ve kütüphanelerin hazineleri de İstanbul'a nakledilmişti. Böylece Kudüs'teki eğitim kurumların sayıları azalarak, ilim merkezi olma eğiliminde rağbet Dımeşk ve Kahire şehirlerine çevrildi (Aslan, 2015: 95).

Kudüs'te ki âlim sayısıyla ilgili değerlendirmelere bakıldığında, XVIII. yüzyılda bir önceki asra göre daha fazla ilim adamının bulunduğu kaydedilirken, sonraki dönemde bu sayıda hızlı bir düşüş olduğu görülmüş ve bu nedenle Kudüs' te faaliyet gösteren okul sayısının otuz beşe düşmesi buna bağlanmıştır. Genel siyasî durum, bozulan maddi durum ve gelir kaynağı olan vakıfların gelirlerinin tükenmesi bu sonucu hazırlayan nedenler arasındadır (El-Aseli, 2002: 337).

Kudüs'te Müslümanların eğitim kurumlarına 1870'li yıllarda baktığımızda 10 Küttab ile bir o kadar da Medrese bulunduğu tespit edilmiştir. Ancak II. Abdülhamid'in öne çıkardığı 'Ümmet Birliği' anlayışı sonucu, Kudüs'teki İptidai Mektep sayısının 300'den fazla olduğu ileri sürülmektedir (İhsanoğlu, 1998: 306).

Osmanlı Devleti'nin hâkim olduğu toprakların tamamında olduğu gibi, Kudüs'te de Hristiyan ve Yahudilerce kurulan bütün dini kurumlar yalnız çocuklara eğitim ve öğretim vermekle kalmıyor, aynı zamanda cemaatlerin diğer kesimlerinin de eğitim ihtiyacını karşılamaya özen gösteriyordu. Bununla da yetinmeyerek bağımsız okullar kurmaktan geri durmuyorlardı. Faal olan Yabancı okulların ekseriyeti Hristiyan misyonerliği gayesiyle var olan bir kuruluşa bağlıydı. Filistin ve tabii ki konumuz olan Kudüs bölgesinde eğitim ve öğretim etkinliklerini ilk başlatan Teşkilat "London Church Missionary Society" adındaki İngiliz Misyonerleri olmuştur. Bu örgüt Kudüs'te "Ingiliz Sanayi Mektebi" adıyla 1839 senesinde, ilkokul seviyesinde kendileri adına girişimlerini başlattılar. 1839-1870 arasındaki 21 senede Sadece Kudüs şehrinde Church Missionary'nin üstün gayretleriyle on dört tane İngiliz Misyoner Okulu açıldı. Tamamına yakını 
ruhsatsız açılan bu okullar, doğru dürüst bir şekilde teftiş edilemiyordu. İngiltere'deki Yahudilerin desteklediği misyoner örgütler, kalabalık gruplar halinde "Mukaddes Beldelerin barış Elçileri!" mesajlarıyla, ideallerini doğrultusunda faaliyetlerde bulunmak için akın akın bölgeye geldiler. Bu örgütler geçmişte taşıdıkları anti-semitist idealleri doğrultusunda öncelikle Musevileri hedef alırken, Ortodoks Rumları da bu konuda aracı olarak seçtiler. Bu İngiliz misyonerler bilinçli bir şekilde kızların eğitimine öncelik verdiler. Bu bağlamda Anadolu'dan da seçilip toplanan bazı Türk kızları bu okullarda tahsil için götürülürken, 1905 'te Kudüs'teki okul sayısı 28'e kadar yükselmişti. Kudüs'te bulunan İngiliz Misyoner Mektebi müdürü ve "Jerusalem Illu Sturafian" adlı makalenin yazarı olan Liz ismindeki biri, Osmanlı Devleti aleyhinde ağır ifadeler içeren makalesindeki ithamlarından dolayı Türk Hükûmeti'nin isteği üzerine İngiliz Konsolosluğu tarafından bölgeden çıkartılmıştır (BOA, Y. PRK. MF. 3/15 1309 (1893-1894)).

XVIII. yüzyıla bakıldığında Kudüs şehrinde İngiliz Protestan ailelerine mensup bulunan toplam 232 kişinin Kudüs merkezinde yaşamasına rağmen, bu sayının çok üzerinde 338 öğrenci okuyabilecek donanıma sahip altı okul binasının bulunması yanında, Protestan papazlar tarafından yedinci okulun da açılması için büyük bir gayret sarf edilmiştir (Saydam, 1999: 465). XIX. yüzyıldaki Amerikan Okullarına gelince, Kudüs'te mevcut üç Amerikan okulundan biri Kız Yatılı Okulu, ikincisi Erkek Yatılı Okulu idi. Bir de bunların yanında Amerikalılar Arkeoloji merkezli eğitim ve öğretim yapan üçüncü bir Okul açmışlardı (Ortaylı, 2000: 331). 1850'li yıllarda Kudüs'te yaşamakta olan Yahudilerin önde gelen isimleri kızlara yönelik mesleki eğitim kurumları açmaya çalışmışlarsa da bu hedeflerini gerçekleştirme başarısı gösterememişlerdir. Fransızların ise Kudüs'te kız için bir dikiş okulu açmaları yanında, Yahudi-Yunan Ortodoks erkek okulu açılmış ve 1860 yııında da Alman Dr. Schneller tarafından yaklaşık 700 öğrencinin okuduğu Suriye yetimler evi kurularak, yetimlere meslek ve dil öğretimine başlanmıştır. Okullardan mesleki faaliyet gösterenlerinde Çini, marangozluk, demircilik gibi meslekler de öğretilmiştir. O dönemde Kudüs'te ki Yahudi Okullarında Tevrat ve Talmud merkezli eğitim ve öğretimin ağırlıklı olması yanında, modern bilimlerin okutulduğu okulların da mevcut olduğu bilinmektedir (Nicault, 2001: 86). Bununla birlikte II. Meşrutiyetin ilanından evvel 1905-1906 yıllarında Kudüs ve çevresinde 350 erkek ve iki kız iptidaisinin resmen faal olduğu bilinmektedir (Baltacı, 1993: 75/Aseli, 2002: 334).

Kudüs'te Yahudilerin eğitim ve öğretim kurumları arasında Tevrat ve Talmud üzerinden eğitimi yürüten okullar bulunduğu gibi, döneme göre yeni gelişmekte olan çağdaş bilimlerle ilgili öğretimini yürüten eğitim kurumları da bulunmaktaydı. 1850'li yıllarda Kudüs'teki Yahudi Toplumu içerisindeki önde gelen isimler de İngilizler gibi öncelikle kız çocuklarının mesleki eğitimi konusuna önem vermişlerdir. Ancak bu faaliyetlerinde pek başarılı oldukları ifade ve iddia edilemez. Yahudi mahallesinin kuzey doğusundaki Yahudiler, Sefarad hahamların desteği ile 1850-1860 yılları arasında, Avusturya himayesinde açılan "Laemel Okulu, Evelyna-de-Rothscild Okulu" gibi genel ve mesleki öğretim kurumlarını işler hale getirmişlerdir. İbranicenin yaygın hale getirilmesi 1880'lerin başlarından itibaren açılan çocuk yuvaları, Almanlar tarafından etkinleştirilen İbrani Öğretmen ve Ticaret okulu, 1889 da faaliyete geçirilen ỉbrani Dili Akademisi ile 1909 de ỉbraniler için açılan Beden Eğitimi Okulu, Siyonistler aracılı̆̆ıyla açılan gece Kursları, çocuk bahçeleri gibi eğitim kurumları sayesinde gerçekleşmiştir. Ayrıca Yahudi öğretim kurumlarının öğretmen ihtiyacını karşılamaya yönelik Öğretmen Okulları, Dini ve Arkeolojik Araştırma Enstitüleri yanında, 1906 yılında Heykeltraş Boris Schartz tarafından Siyonist yardımları sayesinde kendine has yeni bir "Yahudi Sanatı" oluşturmak maksadıyla bir sanat ve zenaat okulu da faaliyete geçirilmiştir (Nicault, 2001: 84).

Osmanlı Türk Cihan Devletinin hâkim olduğu toprakların tamamında olduğu gibi Kudüs Şehrindeki Camilerde de eğitim çocuk yaşlarda başlamakta idi. Bu başlangıç sürecinde çocuklara Kur'ân okuma, yazma ve hesap işleri öğretiliyordu. Şeyh adı verilen Kur'an kursları hocaları eğiticiler idi. Öğrenci okumayı öğrenip Kur'an bir kez tamamen okuyup hatim yaptığında merasim tertipleniyor, yemekler ikram ediliyordu (ihsanoğlu, 1998: 306). 1900 lü yılların başlarında Filistin topraklarında 60'a yakın yerleşkede 78 tane okul vardı ki, bunlardan sadece on dokuzunda kız öğrencilere hizmet verilmekteydi. Okulların tamamında 4.293 öğrenciye 112 erkek, 41 kadın öğretici marifetiyle eğitim-öğretim yapılmaktaydı. Okulların tamamı, eskiden olduğu gibi bu dönemde de Ortodoks Hristiyanlardan sağlanan yardım ve desteklerle faaliyet gösteriyordu. Bu okullar patrikhane tarafından yönetilmekte idiler. Bölgede Arapçanın yaygın olması sebebiyle, öğretim de Arapça idi?

\section{Sonuç}

Kudüs'ün manevi ve politik açılardan taşıdığı önem, halkının da farklı sosyal ve inanış gruplarından olması şehre çok değişik özellikler sağlamıştır. Bu anlamda ortak tarafları fazla olan insanların yaşadığı kentte, yerleşiklerin ortak

\footnotetext{
7 İlay İleri’nin, Ankara Üniversitesi Osmanlı Tarihi Araştırma ve Uygulama Merkezi Dergisi OTAM’da 17. sayı ve 311 -327 sayfalarında yayınlanan çalışmasının dipnotunda “diğer iki bölümünün daha sonra yayınlanacağı" belirtilmişti (sayfa 320, dipnot 37). Bu doğrultuda diğer bölümlerini, Osmanlı Devleti’nde Azınlıkların Eğitimi (II. ve III. Bölümler) başığı ile Yrd. Doç. Dr. İlay illeri, Akdeniz Üniversitesi Eğitim Fakültesi, ilayileri@akdeniz.edu.tr. Adresinden tespit ettik.
} 
çıkarlarının da fazla olması doğaldır. Bu açıdan bakıldığında şehirde yaşayan inanların kimlik belirlenmesindeki temel ortak noktanın din olması, Kudüs'te mevcut olan bütün mekânlara sirayet etmiştir.

Sonuç olarak Kudüs şehrinin kutsal oluşu konusunda ileri sürülenler, her inanışın kendi anlayışı açısından aynı miktarda önem arz eden gerçeklerdir. Bu durum şimdiye kadar olduğu gibi, her inancın mensuplarını kutsal kabul ettiği bölgeye hâkim olma arzusuna yönlendirmesi açısından Kudüs Şehri ve içinde bulunduğu Filistin bölgesi konusundaki tartışmalar hiç sona ermemiştir ve ermeyecektir.

Tarihi vesikalardan elde ettiğimiz bilgiler, Türk Cihan Devleti'nin bu eski ve kutsal beldeye gerek imar ve gerekse yaşayanların her anlamda huzurlu olmaları için büyük bir önem verdiğini göstermektedir. İslâm âleminin önemli mabetlerinden Mescid-i Aksa altı Osmanlı padişahı tarafından onarılması, Eğitim Kurumlarının düzenli bir şekilde ve her inancın mensuplarına uygun tarzda kontrolünün sağlanmasın ile demografik yapının korunmasında takip ettiği metodun adalet ve sosyal yapıya uygunluğu bizi bu sonuca ulaştırmaktadır.

Hz. Ömer'den itibaren Kudüs ve çevresinde hâkimiyet kuran Müslümanların hemen tamamına yakını kendi değer yargılarını dayatmamaları yanında şehir ve bölgede birlikte yaşam doğrultusunda çözümler üretme gayretlerinden vazgeçmeyerek, bölgeye hâkim oldukları sürelerin tamamına yakınında bunu uygulayıp gerçekleştirmişlerdir. Her toplun için kendi inanç ve kültürü doğrultusunda Eğitim Kurumlarının oluşturulmasına özen gösterilmesinden de bu huzurun sağlanması noktasındaki hassasiyetin nasıl korunduğu anlaşılmaktadır. Başka bir ifadeyle Müslüman yöneticiler temeldeki doğruluk iddialarının gerçek olduğunu ve kesin mukaddesatı ifade ettiğini söylerlerken, diğer inançlara sahip olanların mukaddesat tezlerini de tamamıyla görmezden gelmediler. Müslümanlar yanında, diğer inanç sahiplerinin de her anlamda huzurlu yaşamasına imkân tanımaya özen gösterdiler. Ancak I. Siyon Kongresi sonrası Şehre yönelik göç teşviklerinin idealist paralelde artmasıyla Şehirde durumun seyri değişti. Kudüs'te açılan dini ve sosyal kurumlar şehirdeki farklı inanca mensup olan insanlar, Hristiyan mezheplerinde olduğu gibi bir dinin farklı kilise mensupları arasında mücadelelere yol açmaya başladı. Hatta zaman zaman farklı guruplar arasındaki anlaşmazlıklar Devletin barışçı yaklaşımları sonucu büyümeden halledildi.

Böylece Kudüs; Arapçada "selam”, İbranicede "şalom”un anlam karşılığı "barış" şehri olmak yerine, Türk'ün himaye ettiği dönemlerdeki görünümünden uzaklaşıp, aralıksız kavga ve gerilimlerin yaşandığı bir şehir haline dönüştü.

\section{Genişletilmiş Türkçe Özet}

Insanlığın En eski yurtlarından biri yurdu olan Kudüs şehri, 20 ye yakın Peygambere yurt olması açısından daima insanlığın göz bebeği olma özelliğini korumuştur. Bu gerekçeyle dikkatleri üzerinde toplayan güzel belde kendisini ziyaret için gelenlere Tanpınar'ın:

"Ne içindeyim zamanın, Ne de büsbütün dışında;

Yekpare, geniş bir anın Parçalanmaz akışında"

deyişinde ifade ettiği duyguları yaşatan ve yaşanan bütün zamanları kuşatan apayrı bir şehirdir. Manevi atmosferin ruhları heyecanlandırdığı bu mistik coğrafyada nefes almak, insanı zaman yolculuğuna çıkarır da sayısız manevî zevklerle iç içe yaşatırken sanki Ayağınızın yerden kesilip bulutlar arasında olduğunu hissedersiniz.

Kudüs üç büyük Peygamberin olan Hz. Musa, Hz. İsa ve Hz Muhammed tarafından da kutsal bir şehir olarak kabul edilmiştir. Bu özelliğin kattığı değerden dolayı, tarihî dönemler içinde bir türlü paylaşılamamış, sürekli el değiştirmiş; neticede bu topraklarda barut kokusu hiç eksik olmamıştır. Hz. Muhammed (sav)'in Miraç esnasında göklere yükseldiği nokta olarak kabul edilen Mescid-i Aksa'nın bulunduğu Hacer-i Muallaka (askıdaki taş) bu kutlu yer içinde en ilgi çeken noktalardan biridir.

Tarihi vesikalardan elde ettiğimiz bilgiler, Türk Cihan Devleti'nin bu eski ve kutsal beldeye gerek imar ve gerekse yaşayanların her anlamda huzurlu olmaları için büyük bir önem verdiğini göstermektedir. İslâm âleminin önemli mabetlerinden Mescid-i Aksa altı Osmanlı padişahı tarafından onarılması, Eğitim Kurumlarının düzenli bir şekilde ve her inancın mensuplarına uygun tarzda kontrolünün sağlanmasın ile demografik yapının korunmasında takip ettiği metodun adalet ve sosyal yapıya uygunluğu bizi bu sonuca ulaştırmaktadır.

Kudüs'ün hikâyesi üç inanışın ve bu üç inanışa mensup insanların sırlarla dolu hikâyesidir. Çünkü Kudüs deyince bu üç inanışın varoluş mücadelesi ile onların mensupları akla geliyor. Bunlar olmazsa Kudüs de her şehir gibi taştan, ahşaptan, demirden ve betondan pek te cazibesi olmayan bir şehirdir. Bu kadim şehri özel ve güzel kılan onun sıra dışı ruhu ve üzerinde yaşanan olaylardır. Bu olaylardaki sır, şehirde var olan bütün nesnelere sanki birer ruh giydirilmiştir. 
Türk Cihan Devleti bu emsalsiz şehirde farklılıklara rağmen huzurun sağlanması ile her toplum için adil olma yanında kendi inanç ve kültürü doğrultusunda Eğitim Kurumlarının oluşturulmasına özen gösterilmesinde de hassasiyeti korunduğu anlaşılmaktadır. Başka bir ifadeyle Müslüman yöneticiler temeldeki doğruluk iddialarının gerçek olduğunu ve kesin mukaddesatı ifade ettiğini söylerlerken, diğer inançlara sahip olanların mukaddesat tezlerini de tamamıyla görmezden gelmediler. Müslümanlar yanında, diğer inanç sahiplerinin de her anlamda huzurlu yaşamasına imkân tanımaya özen gösterdiler. Ancak I. Siyon Kongresi sonrası Şehre yönelik göç teşviklerinin idealist paralelde artmasıyla Şehirde durumun seyri değişti. Kudüs'te açılan dini ve sosyal kurumlar şehirdeki farklı inanca mensup olan insanlar, Hristiyan mezheplerinde olduğu gibi bir dinin farklı kilise mensupları arasında mücadelelere yol açmaya başladı. Hatta zaman zaman farklı guruplar arasındaki anlaşmazlıklar Devletin barış̧ı yaklaşımları sonucu büyümeden halledildi.

Kudüs'ün hem dini ve hem de siyasi anlamda taşıdığı önem, içi ve çevresinde yaşayan insanların da farklı sosyal yapı ve inanışlara mensup bulunmaları şehre çok değişik özellikler katmaktadır. Bu anlamda ortak tarafları fazla olan insanların yaşadığı kentte, yerleşiklerin ortak çıkarlarının da fazla olması doğaldır. Bu açıdan bakıldığında şehirde yaşayan inanların kimlik belirlenmesindeki temel ortak noktanın din olması, Kudüs'te mevcut olan bütün mekânlara sirayet etmiştir.

Belirttiğimiz ve belirtmediğimiz pek çok konuda taşıdığı manevi değerler yüzünden insanlar için çok muteberdir. "Kudüs adını kutsallığından alması yüzünden Tarihi boyunca kırk defa kuşatılmış, üçünde tamamen olmak üzere 32 defa yıkılmış olduğu için kutsaldır. 26 defa sahiplik değiştirmiş olduğu için; Asur, Babil, Kıpti, Rum, Polemi, Selevsid, Roma, Bizans, Pers, Müslüman Arap, Selçuk, Fatımî, Haçlı, Moğol, Memlûk, Osmanlı, Ingiliz, İsrail, Ürdün, Mısır, Suriye, Lübnan, Irak ve nihayet Filistin bu şehir için savaşmak risk ve heyecanını yaşadığı için kutsaldır."

Bu özellikler tabii ki her insanı Kudüs'ü imceleme heyecanına sevk etmekte, sonuçta bu kutsal şehir için çıkan mücadele ve anlaşmazlıkların idraki için gerekçeleri anlama dürtüsünü zirveye taşımaktadır.

Mescid-i Aksa, bugün darmadağın olan ümmetin yetim çocuğudur. Bulunduğu konumdan bîzardır. Edebiyatımızın son dönemlerinde "Yedi Güzel Adam" olarak değer bulanlardan biri olan Mehmet Akif Inan:

"Mescid-i Aksa'yı gördüm düşümde, Bir çocuk gibiydi ve ağlıyordu,

Varıp eşiğine alnımı koydum, Sanki bir yer altı nehir çağlıyordu"

Deyişiyle, "Mescid-i Aksa" isimli o hissiyat ve gözyaşı çeşmesini andıran güzel şiirinde. Bu boynu bükük mescidin hüzünlü hâli duyarlı her mümin gibi onu da derinden yaralıyordu.

Türk Devleti; Filistin ve Kudüs'e cami, medrese, han, hamam, kemer, köprü, burç, namazgâh, imaret, çeşme, su kanalı, sur, külliye ve çarşı gibi birçok faydalı eser inşa etmiştir. Bu eserlerden biri olan El-Halil'deki II. Abdülhamit Saat Kulesinin, Türklerden sonra şehri ele geçiren ingilizler tarafından vandalca büyük bir tahammülsüzlük örneği göstererek, kuleyi yerinden sökmeleri çok anlamlı değil midir?.

Geçmişte yaşanan ve halen yaşanmakta olan olayları birleştirince: "Kalbimin bir yarısı Mekke, diğer yarısı Medine; üzerinde bir tül gibi Kudüs vardır" ifadelerinde vurgulandığı bir Kudüs akla geliyor ve insan uzaklara dalıp giderken gözleri nemleniyor.

\section{Kaynakça}

Ahmed, C. (1998). Hadika-i Vekâyi. Nşr. Adnan Baycar, TTK, Ankara.

Aksoy, E. (2015). Başlangıcından Günümüze Türkiye'de Fransız Okulları. Synergies Turquiei, 8, 29-46.

Altındağ, ş. (1945). “Kavalalı Mehmet Ali Paşa İsyanı”, s. 54, TTK Basımevi, Ankara.

Armaoğlu, F. (1994). Filistin Meselesi ve Arap İsrail Savaşları (1948-1988). İş Bankası Yayınları, Ankara.

Aslan, H. (2015). Osmanlı Döneminde Kudüs'teki İlmî Hayat, Araştırma İnceleme, isamveri.org > pdfdrg

Avcı, C. (2004). Kudüs (Fethedilişinden Haçlı İstilasına Kadar. DïA, C. XXVI, İstanbul.

Ayverdi, S. (1999). Türk Tarihinde Osmanlı Asırları. IV. Baskı, Kubbealtı Neşriyat (60), İstanbul.

Baltacı, C. (1993). Osmanlı Eğitim Sistemi. Osmanlı Ansiklopedisi I-VII, C. V, s. 75, İstanbul.

Batuk, C. \& Mert, R. (2017). Çatışan Kutsalların Ortasındaki Şehir: Kudüs. Dinbilimleri Akademik Araştırma Dergisi, 17, 129-149.

Buhl, F. (1977). Kudüs. C VI., Milli Eğitim Basımevi, İstanbul. 
Buhl, F. (1986). Kudüs. İA, VI, MEB, İstanbul.

Celâlzâde, M. (1990). Selim-Nâme, Kültür Bakanlığı 1000 Temel Eser, 154, Ankara.

Cohen, J.P. (2017). Osmanlılaşmak: Modern Çağda Sefarad Yahudileri ve İmparatorluk Yurttaşlığı. Alfa Yayınları, İstanbul.

Çakar, E. (2003). XVI. Yüzyılda Şam Beylerbeyliğinin İdari Taksimatı. Fırat Üniversitesi Sosyal Bilimler Dergisi, 13, 351374.

Demirkent, I. (2002). Kudüs (Haçlılar Dönemi). DiA, XXI, İstanbul.

Dolu, A. (2016). Osmanlı Kroniklerinde Kudüs Algısı. Pamukkale Üniversitesi Sosyal Bilimler Enstitüsü Dergisi, 25, 2146.

El-Aseli, K.C. (2002). Kudüs. (Osmanlı Dönemi ve Sonrası). DiA, C. 24., İstanbul.

Emecen, F. (1993). Canberdi Gazâlî. DiA, C. VII., s. 142, İstanbul.

Harman, Ö. F. (2002). Kudüs. DiA, C. XXVI, İstanbul.

Hitti, P. (1995). Siyasi ve Kültürel İslam Tarihi. Çeviren: Salih Tuğ, Marmara Üniversitesi İlahiyat Fakültesi Vakfı Yayınları, C.II., İstanbul.

İhsanoğlu, E. (1998). Osmanlı Eğitim ve Bilim Kurumları, Osmanlı Devleti ve Medeniyeti Tarihi I-II. Cilt 2., s. 306 İstanbul.

Karaman, M. L. (1996). Filistin, DiA, C. 13, İstanbul.

Karaman, M. L. (1992). Uluslararası İlişkiler Çıkmazında Filistin Sorunu, İz Yayıncılık, İstanbul.

Kocabaş, S. (1991). İsrail Devletine Giden Yolda Siyonizm-Osmanlı Devleti İlişkileri, Türk Dünyası Tarih Dergisi, S.56.

Kocabaş, S. (1987). Vaat Edilmiş Toprak Filistin İçin Mücadele Türkiye ve Siyonizm. Vatan Yayınları, İstanbul.

Köse, F. B. (2015). Osmanlı Dönemi Kudüs'ünde İdari Ve Sosyal Yapı. (BELGÜ)Ardahan Üniversitesi İnsani Bilimler Ve Edebiyat Fakültesi Dergisi, 1, 161-199.

Küçük, A. (1992). Yahudilikteki Arzı Mev’ud Anlayışının Boyutları. Ankara Üniversitesi İlahiyat Fakültesi Dergisi, (Ayrıbasım), 33, 101-111.

Memiç, F. (2010). Yahudilik'te ve İslam'da Arz-ı Mev'ud Anlayışı. Yüksek Lisans Tezi, S.Ü. Sosyal Bilimler Enstitüsü.

Nicault, C. (2001). Kudüs 1850-1948. Çeviren: Vali, E.S., İletişim Yayınları, İstanbul.

Oğan, M. (1997). Türkiye-İsrail i̇lişkilerinin Dünü Bugünü ve Yarını. Harp Akademileri Komutanlığı Yayınları, İstanbul.

Öke, M. K. (2002). Siyonizm'den Uygarlıklar Çatışmasına Filistin Sorunu. Ufuk Kitapları, İstanbul.

Öke, M. K. (1981). II. Abdülhamid Siyonistler ve Filistin Meselesi. Kervan Yayınları, İstanbul.

Öksüz, M. (2018). Osmanlı Kudüs'ünde Katolik-Yahudi Münasebetlerine Bir Bakış (XVI. Yüzyıl). FAD- Filistin Araştırmaları Dergisi, 4, 27-41.

Ortaylı, İ. (2000). Osmanlı İmparatorluğunda İktisadi ve Sosyal Değişim. Turhan Kitabevi, Ankara.

Parmaksızoğlu, i. (1985). Seyahat-name: Hatay, Suriye, Lübnan, Filistin. Kültür ve Turizm Bakanlığı, Ankara.

Satış, I. \& Ceyhan, M. (2015). Kudüs Rum Patrikhanesi. Belleten, Cilt: LXXIX-Sayı: 285.

Saydam, A. (1999). Osmanlı Medeniyeti Tarihi. Derya Kitapevi, Trabzon.

Seyyid, E. F. (1995). Fâtımîler. DiA, C. XII, İstanbul.

Tarakçı, M. (2009). Felsefe Ansiklopedisi, (ed. Ahmet Cevizci), Ankara: Ebabil Yayıncılık, c. 6, s. 829-833.

Tokgöz, H. (2001). İsrail Devleti'nin Kuruluşunda Theodor Herzl Ve Siyonizm, ANASAY TC Kültür ve Turizm Bakanlığı GENÇDES, 183-196.

Tomar, C. (2002). Kudüs (Memlükler Dönemi). DiA, C. XXVI, İstanbul.

Türk, F. (2007). Yahudi Devleti'nin Demografik Temelleri: Birinci Dünya Savaşı'na Kadar Osmanlı Devleti'nin Filistin Siyaset. Trakya Üniversitesi Sosyal Bilimler Dergisi, 9, 69-104. 
Türkan, A. (2013). Başlangıcından Günümüze Kudüs Latin Patrikliği. Milel ve Nihal Kültür ve Mitoloji Araştırmaları Dergisi, 10, 29-62.

Uğurlu, T. (2016). XIX. Yüzyılda Kilise Rekabetlerinin Yaşandığı Kudüs'te Osmanlı’nın Uyguladığı Birlikte Yaşama ve Barış Kültürü Politikaları. IMAD-İslâm Medeniyeti Araştırmaları Dergisi, 2, 103-138.

Umar, Ö. O. (2002). Osmanlı Döneminde Yahudilerin Filistin'e Yerleşme Faaliyetleri. Fırat Üniversitesi Sosyal Bilimler Dergisi, 12, 421-438.

Yavuz, E. (1988). "Kudüs Ermeni Patrikhanesi”, Ankara.

Yaycıoğlu, A. (2010). Sened-i İttifak (1808): Osmanlı İmparatorluğu’nda Bir Ortaklık ve Entegrasyon Denemesi. NizamI Kadimden Nizam-ı Cedide; III. Selim ve Dönemi, 667- 709.

Yıldız, H. A. (1989). Ahmed b. Tolun. DiA, C. II, s. 142, İstanbul.

Yiğitoğlu, M. (2017). Hz. Ömer'in Kudüs'ü Fethinden Sonra İzlediği Tapınak Dağı Politikası. Türkiye Illahiyat Araştırmaları Dergisi, 1 135-142.

Zinkeisen, J. W. (2011). Osmanlı İmparatorluğu Tarihi 3, Lehistan Barışı'na ve Sultan I. Mustafa'nın 1623'te Tahttan İndirilmesine Kadar. Çeviren: Ep.eli, N. (Yeditepe) İstanbul.

\section{Gazeteler}

Sabah gazetesi, 15 Receb 1308/24 Şubat 1891

Ekinci, E. B. (2010) Osmanlı Ülkesinde Yahudiler, 06.09.2010 tarihli Türkiye Gazetesi.

\section{Arşiv Belgeleri}

A.DVN. KLS. d, 08/7, "Osmanlı Belgelerinde Filistin", Ed. Hüseyin Özdemir vd. Başbakanlık Devlet Arşivleri Genel Müdürlüğü Yay., s. 441, İstanbul 2009

BOA, HR. SYS., 1768/25, 11 Kasım 1876

BOA, Y. PRK. MF. 3/15 1309 (1893-1894)

COA, İdare-i Dâhiliye, 667-46486, 6 Rebîü'l-âhir 1290 / 3 Haziran 1873

BDA, “Osmanlı Devletinde Filistin", Yay. Nu: 102, Başbakanlık Devlet Arşivleri Genel Müdürlüğü Y., s. 255, İstanbul 2009 Kudüs Şer'iyye Sicilleri, nr. 70, s. 18-50. 